\title{
Genetic Causes of PD: A Pathway to Disease Modification
}

M. Toffoli ${ }^{1}$, S.R.L. Vieira ${ }^{1}$, A.H.V. Schapira ${ }^{1}$

${ }^{1}$ Department of Clinical and Movement Neurosciences, University College London Queen Square Institute of Neurology, London, United Kingdom.

\section{Corresponding author:}

Professor Anthony H V Schapira, MD, DSc, FRCP, FMedSci

Department of Clinical and Movement Neurosciences, University College London Institute of Neurology, London, UK

Rowland Hill St., London NW3 2PF, UK

Email: a.schapira@ucl.ac.uk 


\title{
Highlights:
}

- Parkinson Disease is genetically diverse and a number of different genes have been linked to its pathogenesis.

- No disease modifying therapy for Parkinson disease have been discovered so far, but in recent years many genetically targeted therapies have been proposed.

- The most promising targeted therapies under investigation involve GBA1, LRRK2 and SNCA.

\begin{abstract}
The underline neuropathology of Parkinson disease is pleiomorphic and its genetic background diverse. Possibly because of this heterogeneity, no effective disease modifying therapy is available. In this paper we give an overview of the genetics of Parkinson disease and explain how this is relevant for the development of new therapies.
\end{abstract}

Keywords: Parkinson disease, genetics, LRRK2, GBA1, SNCA, disease modifying, therapy 


\section{Introduction}

Parkinson disease (PD) is the second most common neurodegenerative disease and its prevalence has doubled between 1990 and 2016; in 2016 it was estimated there were over 6 million people with PD that year(Ray Dorsey et al., 2018). Despite significant progress in our understanding of the pathogenesis of the disease, much is still unknown and to date no disease modifying therapy exists. In recent years, the search for a 'cure' for PD has focused on targeting the therapeutic approach on the underlying genetics of PD. In this review, we give an overview of how different genes play a role in the development of PD and how this is relevant for developing future treatments.

\section{The genetic causes of Parkinson disease}

In the 1980s, PD was viewed as a "non-genetic" disease, driven by environmental factors. This concept was supported by the low concordance in twin siblings of PD cases(Eldridge and Ince, 1984; Ward et al., 1983) and by evidence of some toxins and infectious causes of parkinsonism. In 1997, a mutation was identified in the alpha-synuclein gene (SNCA) as the first cause of familial PD (Polymeropoulos et al., 1997). Subsequently, mutations in several different genes were described as causes of familial cases of PD including LRRK2 the most common cause of familial PD described to date(Paisán-Ruíz et al., 2004; Zimprich et al., 2004). Finally, candidate gene and genome wide association studies have identified more genes linked to sporadic forms of PD, e.g. GBA1(Sidransky et al., 2009).

PD can be classified as familial or sporadic, according to the presence or absence of a clear family history, approximately $5-10 \%$ of PD is considered familial. About 3-5\% of familial PD cases show clear Mendelian inheritance and have a known monogenic cause (Kumar et al., 2011). Genes involved in familial monogenic forms of PD have previously been assigned a PARK number, in order of discovery. It is important to remember that the list of PARK genes includes some genes for which evidence is not convincing and is not comprehensive, like in the case of PARK4, initially thought to be a different locus and only later recognised as the previously assigned PARK1 (SNCA). Monogenic forms of PD can be further classified according to their mendelian pattern: LRRK2 is the most common autosomal dominant PD and accounts for around 10\% of all autosomal dominant PD cases(Hernandez et al., 2016), while PRKN accounts alone for almost half of recessive, early onset PD cases(Blauwendraat et al., 2019; Hernandez et al., 2016). Overall, monogenic causes of PD are rare, even the most common, LRRK2 mutations account for $<1 \%$ of PD. In sporadic PD, the majority of sporadic PD cases carry genetic variants that increase the risk of PD. These variants can be viewed either as risk factors or as genetic causes of PD with incomplete penetrance and carriers develop the disease only in the presence of additional "hits", both genetic and environmental. Among these risk factors, LRRK2, GBA1, SNCA and MAPT are most common and the ones that are consistently picked up by GWAS studies(Chang et al., 2017). The most relevant and best understood genes associated with the pathogenesis of PD are listed in table 1. 


\section{One disease, many pathologies}

PD is defined clinically by the presence of parkinsonism (i.e. resting tremor, bradykinesia, postural instability and muscular rigidity) and by the response to treatment with levodopa(Heinzel et al., 2019). The pathological hallmark of PD is the presence of Lewy bodies and Lewy neurites with neurodegeneration in the substantia nigra pars compacta. However, the underlying neuropathology is pleomorphic. For example, some of the genetic forms of parkinsonism e.g. parkin-related do not exhibit Lewy bodies(Johansen et al., 2018).

The heterogenicity of the genes associated with PD also suggests different cellular pathways are involved. PRKN, PINK1 and DJ-1 share a common pathway, related to mitochondrial function and mitophagy. On the other hand, GBA1 is a lysosomal enzyme and $L R R K 2$ also seems to be linked to lysosomal function. Finally, SNCA is directly responsible for altering the expression of alpha-synuclein (A-SYN), the main component of LB. Yet another pathogenic pathway is suggested by the identification of MAPT as a risk gene for sporadic PD(Satake et al., 2009).

This suggests that there are several different causes of the PD phenotype, although some with different pathology and involving different pathways. Understanding the mechanisms by which specific gene mutations result in PD neurodegeneration will enable us to stratify patients, potentially with disease modifying therapies specific to the pathway(s) involved in their disease. 

pattern)

PD

\begin{tabular}{|c|c|c|c|c|}
\hline SNCA/PARK1-4 & yes (Dominant) & yes & Unknown & $\begin{array}{l}\text { Age of onset } \\
\text { dependent on } \\
\text { copy-number, }\end{array}$ \\
\hline PRKN/PARK2 & yes (Recessive) & no & Mitochondrial & Early \\
\hline UCHL1/PARK5 & yes (Dominant) & no & Ubiquitin-proteasome & Late \\
\hline PINK1/PARK6 & yes (Recessive) & no & Mitochondrial & Early \\
\hline DJ-1/PARK7 & yes (Recessive) & no & Mitochondrial & Early \\
\hline LRRK2/PARK8 & yes (Dominant) & yes & Unknown/lysososomal & Late \\
\hline ATP13A2/PARK9 & yes (Recessive) & no & Lysosomal & Early \\
\hline GIGYF2/PARK11 & yes (Dominant) & no & Possibly IGF-1 signaling & Late \\
\hline HTRA2 & yes (Dominant) & no & Mitochondrial & Late \\
\hline PLA2G6/PARK14 & yes (Recessive) & no & Membrane homeostasis & Early \\
\hline FBX07/PARK15 & yes (Recessive) & no & $\begin{array}{l}\text { Ubiquitin- } \\
\text { proteasome/Mitochondrial } \\
\text { function }\end{array}$ & Early \\
\hline VPS35/PARK17 & yes (Dominant) & no & Vesicular trafficking & Late \\
\hline DNAJC6/PARK19 & yes (Recessive) & no & Synaptic endocytosis & Early \\
\hline SYNJ1/PARK20 & yes (Recessive) & no & Synaptic endocytosis & Early \\
\hline DNAJC13/PARK21 & yes (Dominant) & no & $\begin{array}{l}\text { Intracellular vescicular } \\
\text { formation }\end{array}$ & Early \\
\hline CHCHD2/PARK22 & yes (Dominant) & no & Mitochondrial & Late \\
\hline VPS13C/PARK23 & yes (Recessive) & yes & Unknown/Mitochondrial & Early \\
\hline POLG & yes (Dominant) & no & Mitochondrial & Early \\
\hline LRP10 & yes (Dominant) & no & Unknown & Late \\
\hline TMEM230 & yes (Dominant) & no & $\begin{array}{l}\text { Unknown/vesicular } \\
\text { trafficking }\end{array}$ & late \\
\hline EIF4G1 & yes (Dominant) & no & protein synthesis & late \\
\hline MAPT & no & yes & Stabilise axonal microtubules & Late \\
\hline GBA1 & no & yes & Lysosomal & Late \\
\hline KAT8 & no & yes & Autophagy & Late \\
\hline BST1 & no & yes & Immune response & Late \\
\hline MCCC1 & no & yes & Mitochondrial & Late \\
\hline SCARB2 & no & yes & Lysosomal & Late \\
\hline TMEM175 & no & yes & Lysosomal & Late \\
\hline
\end{tabular}

Table 1: genes involved in PD pathogenesis. 


\section{A candidate gene for targeted therapy}

In the past decade, efforts were made to translate the knowledge of the genetics of PD into disease modification.

In this section we discuss what we consider qualify a gene as a good candidate for targeted therapy.

- High prevalence in PD

While PD is a common disease, each gene associated with the disease is present only in a small portion of patients. LRRK2 p.G2019S, possibly the most common mutation associated with sporadic PD, accounts for around $1 \%$ of cases(Healy et al., 2008). If a targeted therapy for PD would be employable only in PD patients carrying a specific mutation, ideally those mutations should be frequent in the PD population.

- Good knowledge of pathogenic mechanism Understanding the pathway that leads from mutations in some genes to PD pathogenesis is crucial in order to develop therapies to reverse these effects.

- Biomarkers

Clinical trials require measurable outcomes to assess efficacy of therapies. To this end, reliable and specific biomarkers are invaluable.

- Relevance of targeted therapy for idiopathic PD

The ongoing clinical trials targeting a specific gene in PD only recruit participants carrying mutations in that gene. However, some of these therapies might be effectively employed in all PD patients. It is the case, for example, with potential therapies for GBA1 mutation carriers. As discussed later in this paper, while GBA1 mutations can increase the risk of developing PD, it is also true that GBA1 activity is perturbed in PD patients without GBA1 mutations(Mazzulli et al., 2011) and it can be postulated that targeting GBA1 could have a beneficial effect in these patients.

The genes involved in the pathogenesis of PD that best meet these criteria are SNCA, GBA1 and LRRK2. Indeed, compounds targeting these genes have made it into clinical trials. They are discussed in sections 5, 6 and 7 and listed in table 2. A graphical representation of the main mechanisms of action of these compounds is provided in figure 1. 


\begin{tabular}{|c|c|c|c|c|c|c|}
\hline $\begin{array}{l}\text { targeted } \\
\text { gene }\end{array}$ & $\begin{array}{l}\text { compound } \\
\text { name }\end{array}$ & $\begin{array}{l}\text { name of } \\
\text { study }\end{array}$ & Sponsor & phase & $\begin{array}{l}\text { completion } \\
\text { year }\end{array}$ & reference \\
\hline \multirow[t]{8}{*}{ SNCA } & NPT200-11 & & $\begin{array}{l}\text { Neuropore } \\
\text { Therapies and } \\
\text { UCB Pharma }\end{array}$ & 1 & 2016 & $\begin{array}{l}\text { CLINICALTRIALS.GOV } \\
\text { ID: NCT02606682 }\end{array}$ \\
\hline & PD03A & AFF011 & Affiris AG & 1 & 2016 & $\begin{array}{l}\text { CLINICALTRIALS.GOV } \\
\text { ID: NCT02267434 }\end{array}$ \\
\hline & PD01A & $\begin{array}{l}\text { AFF008A } \\
\text { A }\end{array}$ & Affiris AG & 1 & 2017 & $\begin{array}{l}\text { CLINICALTRIALS.GOV } \\
\text { ID: NCT02618941 }\end{array}$ \\
\hline & BlIB054 & SPARK & Biogen & 2 & 2022 & $\begin{array}{l}\text { CLINICALTRIALS.GOV } \\
\text { ID: NCT03318523 }\end{array}$ \\
\hline & PRX002 & $\begin{array}{l}\text { PASADE } \\
\text { NA }\end{array}$ & $\begin{array}{l}\text { Hoffmann-La } \\
\text { Roche }\end{array}$ & 2 & 2021 & $\begin{array}{l}\text { CLINICALTRIALS.GOV ID: } \\
\text { NCT03100149 }\end{array}$ \\
\hline & Nilotinib & $\begin{array}{l}\text { PD } \\
\text { Nilotinib }\end{array}$ & $\begin{array}{l}\text { Georgetown } \\
\text { University }\end{array}$ & 2 & 2020 & $\begin{array}{l}\text { CLINICALTRIALS.GOV } \\
\text { ID: NCT02954978 }\end{array}$ \\
\hline & Nilotinib & NILO-PD & $\begin{array}{l}\text { Northwestern } \\
\text { University }\end{array}$ & 2 & 2020 & $\begin{array}{l}\text { CLINICALTRIALS.GOV } \\
\text { ID: NCT03205488 }\end{array}$ \\
\hline & K0706 & PROSEEK & $\begin{array}{l}\text { Sun Pharma } \\
\text { Advanced } \\
\text { Research } \\
\text { Company } \\
\text { Limited }\end{array}$ & 2 & 2021 & $\begin{array}{l}\text { CLINICALTRIALS.GOV } \\
\text { ID: NCT03655236 }\end{array}$ \\
\hline \multirow[t]{4}{*}{ GBA1 } & $\begin{array}{l}\text { GZ/SAR402 } \\
671\end{array}$ & $\begin{array}{l}\text { MOVES- } \\
\text { PD }\end{array}$ & Genzyme & 2 & 2023 & $\begin{array}{l}\text { CLINICALTRIALS.GOV } \\
\text { ID: NCT02906020 }\end{array}$ \\
\hline & Ambroxol & AiM-PD & $\begin{array}{l}\text { University } \\
\text { College, London }\end{array}$ & 2 & 2018 & $\begin{array}{l}\text { CLINICALTRIALS.GOV } \\
\text { ID: NCT02941822 }\end{array}$ \\
\hline & Ambroxol & & $\begin{array}{l}\text { Lawson Health } \\
\text { Research } \\
\text { Institute }\end{array}$ & 2 & 2021 & $\begin{array}{l}\text { CLINICALTRIALS.GOV } \\
\text { ID: NCT02914366 }\end{array}$ \\
\hline & LTI-291 & & $\begin{array}{l}\text { Lysosomal } \\
\text { Therapeutics Inc. }\end{array}$ & 2 & 2018 & $\begin{array}{l}\text { Nederlands Trial Register: } \\
\text { NTR6960 }\end{array}$ \\
\hline \multirow[t]{2}{*}{ LRRK2 } & DNL201 & & $\begin{array}{l}\text { Denali } \\
\text { Therapeutics Inc. }\end{array}$ & 1 & 2019 & $\begin{array}{l}\text { CLINICALTRIALS.GOV } \\
\text { ID: NCT03710707 }\end{array}$ \\
\hline & DNL151 & & $\begin{array}{l}\text { Denali } \\
\text { Therapeutics Inc. }\end{array}$ & 1 & 2020 & $\begin{array}{l}\text { CLINICALTRIALS.GOV } \\
\text { ID: NCT04056689 }\end{array}$ \\
\hline
\end{tabular}

Table 2: List of clinical trials of disease modifying targeted therapies for PD.

Fig.1: Mechanism of action of genetically targeted PD investigational compounds.

\section{SNCA}

\subsection{SNCA as a therapeutic target}

Multiple lines of evidence have implicated the presynaptic neuronal protein, $\alpha$-synuclein (A-SYN), as a therapeutic target in PD. The discovery of the first PD-causing mutation in 1997, an autosomal dominant A53T mutation in the SNCA gene, encoding A-SYN, led to a revolution in genetic research in PD (Polymeropoulos et al., 1997). SNCA duplication and triplication cases were subsequently reported (Chartier-Harlin et al.; Singleton et al., 2003), with a dose effect observed as the age of disease onset is 
proportional to A-SYN gene dosage (Fuchs et al., 2007). The notion of a pathogenic role for A-SYN in PD was further supported by immunohistochemistry studies which revealed aggregated A-SYN as the most significant constituent of Lewy bodies (Baba et al., 1998; Spillantini et al., 1997) and Lewy neurites (Takeda et al., 1998). This pathological form of A-SYN is subject to post-translational modification such as nitration, ubiquitylation, truncation and phosphorylation (Anderson et al., 2006; Fujiwara et al., 2002; Giasson et al., 2000; Tofaris et al., 2003). Experimental model systems also revealed cell-to-cell transmission between interconnected brain regions as key to the pathological spread of A-SYN, in addition to the induction of PDlike motor deficits in wild-type mice following a single intrastriatal injection of fibrillar A-SYN (Luk et al., 2012). Taken together, such evidence highlights the importance of A-SYN not only as a marker of PD but also as an important factor in its pathogenesis (Brundin and Melki, 2017; Sardi et al., 2018). Thus, subsequent research has sought potential therapies attempting to decrease the level of A-SYN or its ability to propagate by targeting key steps in its molecular pathogenesis.

\subsection{Reduction of $\alpha$-Synuclein Production}

One active area of research that has not yet reached clinical phase trial, is aimed at targeting the synthesis of A-SYN prior to its aggregation. RNA interference (RNAi) technologies, which neutralise mRNA molecules, have been used to investigate this. Studies revealed that infusions of short hairpin and small interfering RNA into the striatum and hippocampus of murine and primate models, reduced A-SYN production, even 3 weeks post-infusion (Lewis et al., 2008; McCormack et al., 2010; Sapru et al., 2006), and attenuated progressive motor deficits seen in rotenone-exposed rats (Zharikov et al., 2015). Of note, although these animals demonstrated no signs of toxicity and even SNCA ko mice have no marked deficit, other studies have reported significant degeneration of the nigrostriatal system with a more marked suppression of ASYN production (Collier et al., 2016; Gorbatyuk et al., 2010; Kanaan and Manfredsson, 2012). This suggests that caution must be applied when targeting its production and a safe threshold of suppression must be established.

Another emerging therapeutic approach is to reduce transcription of the A-SYN gene with $\beta 2$ adrenergic receptor $(\beta 2 \mathrm{AR})$ agonists, compounds that regulate the transcription of $\mathrm{A}-\mathrm{SYN}$ through Histone 3 lysine 27 acetylation (Gronich et al., 2018; Mittal et al., 2017). The impact of administering $\beta 2 A R$ agonists in adjunct to levodopa to PD patients has been evaluated in several small open label studies which have reported increased daily time in on phase, reduced latency to treatment response and improved parkinsonism symptoms with this combination therapy (Alexander et al., 1994; Hishida et al., 1992; Uc et al., 2003). However, it is important to note that the utility of $\beta 2 A R$ agonists as an adjunct therapy to levodopa has not yet been assessed in large, randomised controlled trials (Magistrelli and Comi, 2019). An additional promising line of research is aimed at reducing the production of A-SYN by using antisense oligonucleotide (ASO) therapy. Given the recent successes of ASOs in the treatment of spinal muscular 
atrophy (Mercuri et al., 2018) and Huntington disease (Wild and Tabrizi, 2017), researchers have begun to assess the potential use of ASO therapy in PD with studies on rodent models, revealing reduced deposition and spread of A-SYN (Cole et al., 2016).

\subsection{Inhibiting $\alpha$-Synuclein Aggregation}

The misfolding or aggregation of A-SYN and formation of LB results in neurotoxicity. It follows that preventing this could be a neuroprotective therapy for PD. Intrabodies, small antibody fragments which bind to intracellular A-SYN and prevent oligomerization and can be delivered as proteins or genes, are generating significant scientific interest.

Viral vector-based delivery of the intrabodies NbSyn87 and VH14*PEST resulted in reduced aggregated $\alpha$ synuclein and nigrostriatal degeneration, as well as, the restoration of striatal dopamine and motor function in rodents overexpressing $\alpha$-synuclein (Chatterjee et al., 2018). Still in the early stages of exploration for PD targets, intrabodies are yet to reach PD clinical trials with questions such as how to obtain a clinically effective CSF concentration still unanswered.

Two therapies designed to inhibit A-SYN aggregation are currently in early clinical trials. The first, developed by Neuropore Therapies and UCB Pharma, is the small molecule NPT200-11. Studies have revealed improved A-SYN pathology, neuroinflammation and motor function in PD animal models following NPT200-11 administration (Price et al., 2018). A small phase 1 study was also completed in 2016 where NPT200-11 was well-tolerated in healthy volunteers (ClinicalTrials.gov identifier: NCT02606682), and a further phase $1 \mathrm{~b}$ study is being planned (McFarthing and Simuni, 2019). Moreover, a biologic compound NPT088 with high affinity for misfolded proteins (Krishnan et al., 2017; Levenson et al., 2016), originally developed by Proclara Biosciences as a therapy for Alzheimer's Disease, has been shown to bind to aggregated A-SYN, decrease the accumulation of proteinase K-resistant protein and restore levels of tyrosine hydroxylase, required for neurotransmitter synthesis, in PD mouse models (Krishnan et al., 2014).

\subsection{Increasing $\alpha$-Synuclein Clearance}

An alternative strategy, currently in clinical trials, is to enhance the clearance of A-SYN. Therapeutic approaches currently in the clinic include the use of immunotherapies and activation of autophagy pathways.

\subsubsection{Immunotherapies}

Immunotherapy to increase degradation of extracellular A-SYN is in the initial stages of clinical development. Recent discoveries suggesting that extracellular A-SYN is key for aggregate transmission between cells have highlighted the potential of this therapeutic approach in halting PD pathogenesis (Desplats et al., 2009; Lee, 2008; Volpicelli-Daley et al., 2011). Clinical programs utilise two forms of anti-A- 
SYN immunotherapy: passive immunisation, i.e. antibodies specific to A-SYN, and active immunisation, i.e. injections of modified A-SYN that stimulate the endogenous production of antibodies.

The search for passive immunisation therapy for PD has resulted in four active human clinical trials (Lundbeck, Biogen, Roche, Astra Zeneca). The most advanced of these use the humanised IgG1 monoclonal antibodies BIIB-054 and Prasinezumab RO7046015/PRX002 (Zella et al., 2019). In ascending-dose Phase 1 studies, both were well-tolerated and exhibited a greater binding affinity for aggregated A-SYN compared to monomeric(Brys et al., 2019; Jankovic et al., 2018). Recently, both antibodies have entered Phase 2 studies where approximately 300 early PD patients have been recruited. The SPARK trial aims to evaluate safety and pharmacokinetic/pharmacodynamic profile of BIIB-054 (ClinicalTrials.gov Identifier: NCT03318523), as opposed to a change in total MDS-UPDRS scores with PRX002 in the PASADENA trial (ClinicalTrials.gov Identifier: NCT03100149). In addition, one active immunotherapy vaccine has successfully completed Phase 1 trials (AFFITOPE PD01A/PD03A, AFFiRiS, Austria). In patients with earlystage PD, good levels of immunogenicity were reported alongside no serious adverse events (ClinicalTrials.gov Identifiers: NCT02267434; NCT02618941). These studies were neither designed nor powered to assess clinical efficacy (McFarthing and Simuni, 2019).

It is notable that further active and passive immunisation approaches are in development; AbbVie launched a Phase I trial of ABBV-0805 and United Neuroscience's UB312 project is due to enter Phase 1 trials in 2019 (McFarthing and Simuni, 2019). However, immunotherapy as means to increase A-SYN degradation has some difficulties: inducing off-target responses; need for frequent administration; lack of immune response (specific to active therapy) and whether the limited penetration of antibodies into the central nervous system (CNS) is sufficient to result in significant clearance of A-SYN (Lindström et al., 2014). However, the finding that the antibody aducanumab reduced brain amyloid-beta plaques in patients with Alzheimer's Disease supports the notion that a clinically effective CNS antibody concentration can be obtained (Sevigny et al., 2016).

\subsubsection{Autophagy-enhancing agents}

Autophagy is one of the main routes for the degradation of intracellular A-SYN aggregates (Webb et al., 2003; Xilouri et al., 2016) and the potential of autophagy-enhancing agents as a neuroprotective therapy for PD is under current investigation. Rapamycin acts via the mammalian target of rapamycin (mTOR), known to regulate macroautophagy. Studies have shown that rapamycin reduced A-SYN aggregation and associated neurodegeneration in PC12 cells expressing wild-type or mutant A-SYN (Webb et al., 2003), and in A-SYN-overexpressing rats (Decressac et al., 2013) and mice (Crews et al., 2010). Similarly, lithium is another autophagy enhancer and its neuroprotective effects have been repeatedly reported in both in vitro and in vivo models (Forlenza et al., 2014). However, both rapamycin and lithium lack specificity, interfering 
with various cellular pathways, and cause side-effects, making them unsuitable for use as a prolonged highdosage therapy.

Recent studies have also indicated that the mitochondrial pyruvate carrier (MPC) inhibitor, MSDC0160, acts to block the mTOR pathway (Ghosh et al., 2016). MSDC-0160 administration protects dopaminergic neurones against 1-methyl-4-phenylpyridinium (MPP+) insult in cell and animal models, attenuating disease progression in two mouse models of PD(Ghosh et al., 2016). mTOR inhibition and its subsequent enhancement of autophagy is believed to be the mechanism by which MSDC-0160 halts neurodegeneration (Ghosh et al., 2016). In addition, further support for the neuroprotective effect of MPC inhibition originates from the finding that MPC inhibitor UK-5099 prevents damage to cortical neurones following excitotoxic injury by regulating glutamate release (Divakaruni et al., 2017; Vacanti et al., 2014). Taken together, investigations of MSDC-0160 suggest that MPC inhibition could be used as a therapeutic approach to reduce $\alpha$-synuclein aggregation, but it is important to note that a demonstration that this can be achieved in mammalian disease models is required first.

Interestingly, anti-cancer drugs have emerged as a promising approach to enhance autophagic clearance. Nilotinib, used as second-line treatment for chronic myelogenous leukaemia, acts as an inhibitor of Abelson murine leukemia viral oncogene homolog 1 (c-Abl) and is under investigation as a PD therapy. Increased c-Abl activity has been reported in brain tissues of PD patients and can lead to an increase in ASYN phosphorylation and aggregation (Brahmachari et al., 2016; Lindholm et al., 2016). An increase in c-Abl levels has also been shown to reduce the function of Parkin, a key mediator of mitophagy (Lonskaya et al., 2014). Nilotinib administration prevented dopaminergic neuron loss (Karuppagounder et al., 2014) and normalised striatal motor behaviour in MPTP-treated mice (Tanabe et al., 2014), through to increase in ASYN deposition into lysosomes where it is degraded (Hebron et al., 2013). Further, a small open-label safety trial evaluated the effects of nilotinib in 12 patients with advanced PD and dementia with Lewy bodies, where a beneficial effect on motor/non-motor symptoms and changes in surrogate disease markers such as A-SYN levels and dopamine metabolism were reported (Pagan et al., 2016). Despite significant caveats with this study which included a lack of a placebo group and non-homogenous cohort of participants (resulting in intra and inter-group baseline differences) (Wyse et al., 2016), these findings prompted further investigations. Specifically, larger, randomised, placebo-controlled, double blind Phase lla trials are ongoing to determine the tolerability and safety of nilotinib administration, as well as evaluate whether sufficient CNS penetration is possible at non-toxic drug concentrations (ClinicalTrials.gov Identifiers: NCT02954978 and NCT03205488) (Pagan et al., 2019). Another c-Abl compound, K0706, is currently being tested in the PROSEEK study, a phase 2 randomised trial (ClinicalTrials.gov Identifier: NCT03655236). Aim of the PROSEEK study is to assess safety and efficacy of K0706 in early PD patients.

\subsection{Specific challenges with SNCA targeted therapy}


Despite being a promising pathway to disease modification in PD, key obstacles and unanswered questions hinder the development of neuroprotective therapies targeting A-SYN. Main challenges are an incomplete understanding of the complexity of the pathogenesis of this disease in addition to a lack of measurable end-points and preclinical models.

First, although the involvement of A-SYN toxicity is well-established in the pathogenesis of PD, its exact contribution relative to other key molecular events (e.g. inflammation, impairment of autophagy, Iysosomal/mitochondrial dysfunction, oxidative stress) has been the source of frequent debate (Burré et al., 2018; Dehay et al., 2015; Oueslati, 2016). In particular, it remains unclear whether A-SYN aggregation initiates cellular dysfunction or vice versa. Therapies targeting A-SYN will have limited efficacy in ameliorating PD symptoms if A-SYN aggregation is not the primary cause of disease.

Second, conflicting reports regarding the pathogenic conformation of A-SYN have complicated efforts to develop a therapy targeting this protein. A-SYN, long described as a natively unfolded $\sim 14 \mathrm{kDa}$ monomer (Burré et al., 2013; Theillet et al., 2016; Weinreb et al., 1996), can take up various conformations physiologically including: dimers; trimers; tetramers and higher-molecular-weight soluble oligomers which can subsequently, become insoluble fibrils with a 1000-fold increase in toxicity compared to oligomers (Pieri et al., 2012). Moreover, tetrameric A-SYN seems to be more resistant to aggregation (Bartels et al., 2011; Tsika et al., 2010), and distinctive aggregation properties are associated with different $\alpha$-synuclein strains (Mamais et al., 2013). Thus, a more comprehensive understanding of the pathogenic properties of different $\alpha$-synuclein conformations in PD is key when establishing which form emerging therapies should target (Melki, 2015; Peng et al., 2018).

Third, the role of post-translational modifications of A-SYN is not fully understood. Although hyperphosphorylation of serine residue 129 of A-SYN in LB is a specific pathological hallmark of PD (Anderson et al., 2006; Saito et al., 2003), its relevance to initiating and exacerbating disease has been questioned on the finding that it only accounts for $5 \%$ of all A-SYN (Kellie et al., 2014) and experimental studies modifying the phosphorylation of A-SYN have generated conflicting results (Chen and Feany, 2005; Lee et al., 2011; Oueslati et al., 2013; Sato et al., 2011). Moreover, A-SYN can undergo truncation at the Cterminus by calpains (Dufty et al., 2007). It is notable that calpain inhibitors reduce A-SYN deposition in transgenic mouse models (Diepenbroek et al., 2014; Hassen et al., 2018), although the converse, i.e. an enhancement of A-SYN pathology, is not observed with increased calpain activity (Diepenbroek et al., 2014). Additional work is thus required to determine the relevance of Ser129 phosphorylation and truncated $\alpha$-synuclein in PD pathogenesis in order to establish the validity of therapies targeting these modifications.

Lastly, animal models are only partially successful in replicating the A-SYN pathology of PD. Transgenic mouse models under current investigation only express $30-50 \%$ of dopaminergic neuronal loss (Janezic et al., 2013; Thiruchelvam et al., 2004; Wakamatsu et al., 2008). Alternatives, such as viral vector-mediated 
overexpression models, demonstrate greater nigrostriatal degeneration however, are also more labour intensive and subject to greater variability (Dehay and Fernagut, 2016).

In addition, the field would benefit from the development of imaging techniques to map the extent of A-SYN pathology in patients and by the development of a biofluid-based biomarker, neither of which are currently available (Sardi et al., 2018).

\section{GBA1}

\subsection{GBA1 as a therapeutic target}

There are over 300 GBA1 mutations known to be pathogenic for the lysosomal storage disorder Gaucher Disease (GD)(Hruska et al., 2008). GD is an autosomal recessive disease and heterozygous GBA1 mutations carriers allele do not develop the disease. This view has changed in recent years with the recognition that GBA1 mutations, both monoallelic and biallelic, are also risk factors for PD, and the estimated odds ratio for any GBA1 mutation in PD patients versus controls is 5.43 according to a big multicentric study(Sidransky et al., 2009). Moreover, GBA1 mutations are highly prevalent in sporadic PD cases, with the two most common mutations being present in 3-7\% of patients(Lesage et al., 2011; Neumann et al., 2009; Sidransky et al., 2009)..

The mechanisms that links GBA1 and PD have not been fully elucidated yet and potentially include a number of different cellular mechanisms, possibly mutation specific. Glucocerebrosidase (GCase), the product of expression GBA1, is a lysosomal enzyme. Its main substrate is glucosylceramide (GC), that is hydrolysed into glucose and ceramide. The systemic manifestations of GD are mainly caused by the accumulation of GC, especially in macrophages. While less clearly supported by experimental evidence(Matthew E Gegg et al., 2015), substrate accumulation seems to play a role also in the pathology of neuronopathic GD and of GBA1-PD(Kim et al., 2018; Rocha et al., 2015; Suzuki et al., 2015). In particular, human dopaminergic induced pluripotent stem cells (iPSCs) with GBA1 mutations show accumulation of ASYN and GC(Schöndorf et al., 2014a), that can be reverted by treatment with an inhibitor of the enzyme GC-synthase(Kim et al., 2018). Also rats treated with the GCase inhibitor conduritol B epoxide show increased levels of A-SYN(Manning-Boğ et al., 2009).

A second proposed mechanism is related to the misfolding of mutant GCase. Usually, GCase travels from the endoplasmic reticulum (ER) to the Golgi and on to the lysosomes, but some GBA1 mutations might interfere with this process. The mutant GCase would then cause saturation of the ubiquitin-proteasome and ER associated protein degradation systems, leading to the inability of the cell to degrade other proteins, like A-SYN.(Bendikov-Bar and Horowitz, 2012; Fernandes et al., 2016; Schöndorf et al., 2014b). Other possible mechanisms that could link GBA1 mutations and PD are mitochondrial disfunction and inhibition of autophagy(Gegg and Schapira, 2018; Toffoli et al., 2020). 
Very interestingly, it seems that there is a bidirectional feedback between GCase and A-SYN and that A-SYN accumulation can lead to decrease GCase deficiency(Gegg et al., 2012; Mazzulli et al., 2011). This finding suggests that targeting GCase might have an effect on A-SYN pathology even in PD patients that do not carry GBA1 mutations.

\subsection{Translational studies}

The systemic manifestations of GD can be treated by administering GCase through periodic infusions. However, enzyme replacement therapy (ERT) is unable to cross the blood brain barrier and is thus not useful in treating the neuronopathic manifestations of GD, nor can it be employed to treat GBA1-related PD. Alternative strategies have been implemented to treat GBA1-PD, the most promising being substrate reduction therapy and small molecule chaperones.

\subsubsection{Substrate reduction therapy}

Substrate reduction therapy (SRT) is a viable alternative to ERT for the treatment of GD(Pastores and Hughes, 1993). SRT acts by inhibiting the enzyme GC-synthase, thus reducing the accumulation of GC when GCase activity is low. Given its ability to cross the blood brain barrier (BBB), SRT might be effective in alleviating the GBA1-PD pathology.

GZ667161 is a GC-synthase inhibitor able to improve lifespan and reduce brain pathology in a mouse model of neuronopathic GD after peritoneal administration(Cabrera-Salazar et al., 2012).

In a mouse model homozygous for the GBA1 mutation p.D409V, oral treatment with GZ667161 reduced the accumulation of GC and of Lewy Bodies (LB) and improved cognitive outcomes (Sardi et al., 2017). Interestingly, GZ667161 was able to produce similar results in a mouse model of synucleinopathy, carrying mutant SNCA but wild type GBA1 genes(Sardi et al., 2017). On the basis of these findings, in 2016 SanofiGenzyme launched a phase 2 double-blinded clinical trial with venglustat (GZ/SAR402671), an analogue of GZ667161, in GBA1-PD patients (ClinicalTrials.gov identifier: NCT02906020). The trial is expected to close in 2021-2023.

Of note, some concern regards tolerability of SRT, as it can consistently cause side effects, in particular diarrhea(Stirnemann et al., 2017).

\subsubsection{Chaperoning GCase to the lysosome}

A different strategy for the therapy of GBA1-PD is to facilitate the transport of mutant GCase to the lysosomes, increasing its activity and reducing the level of unfolded proteins in the ER/cytoplasm. This has been achieved in experimental settings through the use of small molecule chaperones (SMCs). SMCs are classified as inhibitory and non-inhibitory. Inhibitory SMCs bind the active site of GCase and inhibit the enzyme until it reaches the lysosomes, where the low $\mathrm{pH}$ dissociates the chaperone from the GCasem and 
reverses the inhibition. Non-inhibitory SMCs bind to a different site and do not have inhibitory activity. The first inhibitory SMCs described, NN-DNJ, was able to increase GCase activity in vitro in fibroblasts with a GBA1 mutation(Sawkar et al., 2002). NN-DNJ is part of a class of compounds called iminosugars and after the promising results with NN-DNJ, other iminosugars were tested (Mena-Barragán et al., 2016; Steet et al., 2006). One of them, isofagomine was studied in a phase 1 clinical trial, but failed to show significant improvements in GD patients(Shayman and Larsen, 2014). As a class, iminosugars have a strong inhibitory activity toward GCase that makes it difficult to find a therapeutic window. Other non-iminosugar inhibitory SMCs have been identified in the following years(Zheng et al., 2007) and recently a new molecule, ambroxol, has gained a lot of attention. Ambroxol was able to increase GCase activity in GD fibroblasts in vitro(Maegawa et al., 2009) and reduced A-SYN accumulation in a mouse model of PD(Migdalska-Richards and Schapira, 2016). This lead to the initiation of 2 clinical trials on ambroxol in PD patients. The first one is an phase IIA prospective, single-center, open label clinical trial to evaluate the safety, tolerability and pharmacodynamic effects of ambroxol in 20 PD patients with or without GBA1 mutations. It started in 2016, recently completed the data collection phase and is currently in press(ClinicalTrials.gov identifiers: NCT02941822). The second one is a randomized, placebo-controlled trial in 75 patients with PD dementia, started in 2015 and expected to terminate in 2021 (ClinicalTrials.gov identifiers: NCT02914366). Of the non-inhibitory SMCs, the compounds NCGC00188758 and NCGC607 showed the ability to lower ASYN accumulation and downstream pathology in dopaminergic neurons derived from patients with GBA1PD(Aflaki et al., 2016; Mazzulli et al., 2016). Lysosomal Therapeutics Inc. is running a clinical trial on LTI-291, a non-inhibitory SMCs (Netherlands Trial Register: NTR6960). The trial is a phase 2 randomized, placebocontrolled, double-blind study and recruitment was completed in 2018.

\subsubsection{Gene therapy}

Gene therapy consists of using viral vectors to insert wild type GBA1 alleles into the genome of GBA1 mutation carriers. If successful, gene therapy would be able to restore normal GCase activity, curing GD and possibly nullifying the increased risk of PD in GBA1 mutation carriers. Promising results have been achieved with gene therapy in animal models of GD. Using a spleen focus-forming virus and a self-inactivating lentiviral vector, two different groups were able to transfect a normal GBA1 gene in bone marrow cells of a mouse model of GD. After reinfusing the transfected cells into the animals, the animals corrected the GD phenotype(Dahl et al., 2015; Enquist et al., 2006).

In 2019, a gene therapy for spinal muscular atrophy using the adeno-associated virus AAV-9 vector was approved by the FDA(Dangouloff and Servais, 2019). This prompted Prevail Therapeutics to announce that they are starting a phase 1-2 clinical trial with a GBA1 gene therapy program, PR001, using the same AAV-9 as a vector. 


\subsection{Specific challenges with GBA1 targeted therapy}

The main obstacle in developing a GBA1 targeted therapy for PD is that the underlying pathogenesis has not been fully clarified yet. Whether A-SYN accumulation in dopaminergic neurons of patients with GBA1 mutations is caused by accumulation of substrates of GCase, by saturation of the ubiquitin-proteasome pathway or by alternative mechanisms is still a matter of debate.

First, while substrate accumulation plays a clear role in the systemic manifestations of GD, it is uncertain whether it is also a factor in the neurological manifestations of GBA1-PD. Indeed, while many studies suggest that SRT is effective in animal models of GBA1-PD, several studies did not observe accumulation of GC in the brain of PD patients with or without GBA1 mutations(Boutin et al., 2016; Clark et al., 2015; Matthew E. Gegg et al., 2015) and only one study showed increased levels of glucosylsphingosine, a secondary substrate of GCase, in the hippocampus of PD patients without GBA1 mutations(Rocha et al., 2015). If substrate accumulation does not take place in the brain of GBA1-PD patients or in that of idiopathic PD patients, then SRT is less likely to have an impact on the pathology.

A second limitation regards the multitude of GBA1 mutations linked to PD. Indeed, these mutations affect GCase activity and its conformation in different ways(Gan-Or et al., 2015; Smith et al., 2017), and there are some mutations that are pathogenic for PD but do not cause GD, like p.E326K(Siebert et al., 2014). These differences imply that targeted therapies that are effective on some mutations might not be effective on others. For example, p.E326K produces a very modest decrease in GCase activity(Malini et al., 2014) and thus substrate reduction therapy might have less effect on this mutation.

Finally, even though gene therapy inserts a wild-type GBA1 gene in the genome of mutation carriers, the mutant GCase protein is still translated and it is possible that this misfolded GCase can still cause A-SYN pathology. Indeed, the majority of patients with GBA1-PD are heterozygous for GBA1 mutations, suggesting a gain-of-function mechanism.

\section{LRRK2}

\subsection{LRRK2 as a therapeutic target}

LRRK2 mutations are the most frequent genetic variants in familial PD. The p.G2019S mutation, the most common $L R R K 2$ mutation, is found in approximately $1 \%$ of sporadic PD cases and $4 \%$ of familial PD cases according to a multicenter study conducted in 2008(Healy et al., 2008). In Ashkenazi Jewish and North African populations the frequency is significantly higher, respectively 14.3\%-18.8\%(Orr-Urtreger et al., 2007; Ozelius et al., 2006) and 39.3\%(Hulihan et al., 2008). More than 100 LRRK2 mutations have been described(Rubio et al., 2012), but only 6 of them have been associated to PD by linkage: p.R1441C, p.R1441G, p.R1441H, p.Y1699C, p.I2020T and p.G2019S, with the latter being by far the most common(Healy et al., 2008; Lorenzo-Betancor et al., 2012). These mutations show a relatively high 
penetrance and were described in familial forms of PD. The penetrance of the p.G2019S mutation is estimated to be $42.5-74 \%$ by the age of 80 in non-Ashkenazi Jewish(Healy et al., 2008; Lee et al., 2017) and $25 \%$ in the Ashkenazi Jewish population(Marder et al., 2015). Several other variants have been described as risk factors for sporadic PD by association studies. These variants are common in the general population, but increase the risk of developing PD by various degrees(Ross et al., 2011; Wu et al., 2012). The LRRK2 protein has both GTPase and kinase activity and mutations that are pathogenic for PD seem to act by increasing the protein's kinase activity both in vitro(West et al., 2005) and in vivo(Sheng et al., 2012). The pathological mechanism of LRRK2 mutations has been investigated in iPSC and animal models. From cellular models, it emerged that p.G2019S can lead to disorganization of the nuclear membrane, mitochondrial dysfunction and intracellular calcium homeostasis(Cooper et al., 2012; Howlett et al., 2017; Liu et al., 2012; Schwab and Ebert, 2015). In all cases, correction of the genotype or inhibition of LRRK2 kinase activity reversed the pathology. One cellular model also investigated the pathogenic mutation p.R1441C, with similar findings(Cooper et al., 2012). Additional evidence from animal models shows that the p.G2019S mutation induces dopamine neurons pathology(Xiong et al., 2018) that can be reversed by administration of LRRK2 kinase inhibitors(Lee et al., 2010). Moreover, LRRK2 inhibitors have proved effective in contrasting induced alpha-synuclein pathology in LRRK2 mutated or, interestingly, wild-type mice(Bae et al., 2018; Lavalley et al., 2016; Qin et al., 2017).

Numerous studies have shown an alteration of LRRK2 function in PD pathology associated with other PD causing mutations. The vacuolar protein sorting associated protein 35 (VPS35), causing autosomal dominant forms of PD(Vilariño-Güell et al., 2011), has been associated to LRRK2 and, very interestingly, VPS35 mutants show increased phosphorylation of Rab10, substrate of LRRK2(Mir et al., 2018). Similarly, LRRK2 has been linked to PINK/PRKN pathology in iPSCs and pharmacological inhibition of LRRK2 in vitro was able to partially recover PINK/PRKN related impaired mitophagy(Bonello et al., 2019). Even more important, LRRK2 kinase activity is increased in sporadic PD cases without LRRK2 mutations(Di Maio et al., 2018) and some mild evidence suggests that treatment with LRRK2 kinase inhibitors might attenuate A-SYN pathology in cell and animal models of PD without LRRK2 mutations(Andersen et al., 2018a; Smith et al., 2016).

Taken together, these data suggest that kinase inhibition of LRRK2 might be beneficial in A-SYN pathology in $L R R K 2$ mutated individuals and possibly also in $L R R K 2$ wild type PD individuals.

\subsection{Inhibition of LRRK2 kinase activity}

To reverse $L R R K 2$-related PD pathology, efforts have concentrated on reducing LRRK2 kinase activity. The earliest compounds were non-selective kinase inhibitors, unable to cross the BBB and with low potency(Anand et al., 2009; Covy and Giasson, 2009; Nichols et al., 2009). Nonetheless, they led to the development of a new generation of selective compounds, more active in inhibiting LRRK2 kinase activity 
and with fewer off-target effects, even though they were still not reaching good concentrations in the brain(Deng et al., 2011; Ramsden et al., 2011; Yao et al., 2013). HG10-102-01 was the first compound capable of crossing the BBB and showed $L R R K 2$ inhibition in the brain of mice following intra-peritoneal delivery(Choi et al., 2012). This was a major advancement in the field and allowed the design of a second generation of selective LRRK2 inhibitors. Following HG10-102-01, other BBB penetrant small molecule inhibitors were developed, like GNE-7915 GNE-0877, GNE-9605, JH-II-127, TAE684 and PF-06447475. Together with a higher efficacy, these compounds came with oral availability, although the pharmacokinetic properties were still not suitable for clinical trials(Estrada et al., 2014, 2012; Hatcher et al., 2015; Henderson et al., 2015; Zhang et al., 2012). This preclinical research culminated in the development of 2 compounds with exceptional potency and selectivity in inhibiting LRRK2 kinase activity, optimal brain penetration and pharmacokinetics and a good safety profile: MLi-2 and PFE-360(Andersen et al., 2018b; Fell et al., 2015; Scott et al., 2017).

MLi-2 was able to reduce $L R R K 2$ kinase activity in the brain of mice by $90 \%$ after 1 hour of administration and proved highly selective when tested against over 300 kinases. Moreover, it didn't cause any adverse effect after reaching brain and plasma concentrations 100 times higher than the $I_{50}$. Of note, MLi-2 was not able to reverse PD pathology in a mouse model of mitochondrial dysfunction related to PD(Fell et al., 2015). PFE-360 gave similar results in rats, with almost complete peripheral inhibition of LRRK2 kinase activity after $1 \mathrm{~h}$ of oral exposure(Andersen et al., 2018b).

On the basis of these findings, Denali therapeutics began testing two promising compounds in humans. DNL201 was already tested in a phase 1a trial on 122 healthy subjects and now entered phase $1 \mathrm{~b}$ in PD patients with and without $L R R K 2$ mutations to assess safety, pharmacodynamics and pharmacokinetics. Closing date for this trial was September 2019 (ClinicalTrials.gov Identifier: NCT03710707). A similar compound, DNL151 also entered phase $1 \mathrm{~b}$ trial with the same design, with estimated completion date in February 2020 (ClinicalTrials.gov Identifier: NCT04056689).

\subsection{Specific challenges with LRRK2 therapy}

Despite the promising results achieved so far and the expectations for the ongoing clinical trials, LRRK2 targeted therapy faces several challenges.

First, toxicity is a potential concern. To assess the effect of loss of LRRK2 kinase activity, LRRK2 deficient animal models were studied, with the discovery of abnormalities in the kidneys and lungs(Herzig et al., 2011). In particular, LRRK2 knock-out (KO) mice displayed lysosomal changes in kidney proximal tubule cells and accumulation of lamellar bodies in type 2 pneumocytes(Herzig et al., 2011). In a second mouse model carrying a LRRK2 kinase inhibitory mutation, the same alterations were observed in the kidneys but not in the lungs(Herzig et al., 2011). In KO mice kidneys showed macroscopic changes in weigh, color and size(Tong et al., 2012). These lungs and kidney alterations were also observed in LRRK2 KO rats and were 
linked to serum and urine abnormalities(Baptista et al., 2013; Ness et al., 2013). Additionally, KO rats alterations in liver and spleen were reported, but not reproduced in different experiments(Baptista et al., 2013; Ness et al., 2013). The same alterations in lungs and kidneys were observed in mice treated with LRRK2 kinase inhibitors MLi-2 and PFE-360, confirming that their cause is likely to be a reduction in LRRK2 kinase activity(Andersen et al., 2018b; Fell et al., 2015). A potential effect of $L R R K 2$ inhibition on immune response has also been postulated (Zhao and Dzamko, 2019). Of note, all the adverse effects observed in animals after pharmacological inhibition of LRRK2 were reversible and did not affect lifespan.

A second limitation in the development of $L R R K 2$ targeted therapies is the lack of specific biomarkers. The most widely used measure of LRRK2 kinase activity in vivo is by quantifying phosphorylation levels of two serine residues in the LRRK2 protein, Ser910 and Ser935(Dzamko et al., 2010). Indeed, a number of $L R R K 2$ kinase inhibitors showed the ability to reduce phosphorylation of Ser910 and Ser935(Andersen et al., 2018b; Fell et al., 2015). However, this approach presents some limitations. First, incubating LRRK2 in vitro after treatment with kinase inhibitors and then washout of the drugs demonstrates unphosphorylated Ser910 and Ser935. This suggests that Ser910 and Ser935 are not the product of autophosphorylation and as such are not a direct measurement of LRRK2 enzymatic activity (Dzamko et al., 2010). Second, some LRRK2 mutations, like R1441C, a mutation that is supposed to increase kinase activity(West et al., 2005), shows lower levels of phosphorylation of Ser910 and Ser935(Dzamko et al., 2010). If we accept the theory that PD causing pathogenic mutations in LRRK2 act by increasing kinase activity, it seems counterintuitive that mutations like R1441C decrease phosphorylation. It is possible that these mutations produce structural abnormalities in the LRRK2 protein that make it less prone to phosphorylation by other enzymes(Dzamko et al., 2010). Even if this is the case, measuring Ser910 and Ser935 phosphorylation seems unsuitable to assess LRRK2 activity in the presence of these mutations.

An alternative method is measuring phosphorylation of $L R R K 2$ kinase substrate Rab10(Steger et al., 2016; Thirstrup et al., 2017). However, phosphorylation of Rab10 was not increased in neutrophils of p.G2019S mutation carriers, suggesting it might not be a reliable indicator of $L R R K 2$ activity either(Fan et al., 2018). This might be explained by the presence of addtional limiting factors for the phosphorylation of Rab10 by LRRK2(Liu et al., 2018). In summary, we are still missing a reliable marker of $L R R K 2$ activity and the best approach for the moment seems to be measuring phosphorylation of Ser910 and Ser935 together with phosphorylation of Rab10(Zhao and Dzamko, 2019).

\section{Conclusions}

Research on a genetically targeted therapy for PD is moving rapidly and provides promising results for the development of disease modification. However, a better understanding of the underlying pathogenesis of PD and the development of specific biomarkers is required in order to support the development of these new drugs. 
This research did not receive any specific grant from funding agencies in the public, commercial, or not-for-profit sectors. 


\section{Bibliography}

Aflaki, E., Borger, D.K., Moaven, N., Stubblefield, B.K., Rogers, S.A., Patnaik, S., Schoenen, F.J., Westbroek, W., Zheng, W., Sullivan, P., Fujiwara, H., Sidhu, R., Khaliq, Z.M., Lopez, G.J., Goldstein, D.S., Ory, D.S., Marugan, J., Sidransky, E., 2016. A new glucocerebrosidase chaperone reduces $\alpha$-synuclein and glycolipid levels in iPSC-derived dopaminergic neurons from patients with Gaucher disease and parkinsonism. J. Neurosci. 36, 7441-7452. https://doi.org/10.1523/JNEUROSCI.0636-16.2016

Alexander, G., Schwartzman, R., Nukes, T., Grothusen, J., Hooker, M., 1994. Beta 2-adrenergic agonist as adjunct therapy to levodopa in Parkinson's disease. Neurology 44, 1511-3.

Anand, V.S., Reichling, L.J., Lipinski, K., Stochaj, W., Duan, W., Kelleher, K., Pungaliya, P., Brown, E.L., Reinhart, P.H., Somberg, R., Hirst, W.D., Riddle, S.M., Braithwaite, S.P., 2009. Investigation of leucine-rich repeat kinase 2. FEBS J. 276, 466-478. https://doi.org/10.1111/j.1742-4658.2008.06789.x

Andersen, M.A., Christensen, K.V., Badolo, L., Smith, G.P., Jeggo, R., Jensen, P.H., Andersen, K.J., Sotty, F., 2018a. Parkinson's disease-like burst firing activity in subthalamic nucleus induced by AAV- $\alpha$-synuclein is normalized by LRRK2 modulation. Neurobiol. Dis. 116, 13-27. https://doi.org/10.1016/j.nbd.2018.04.011

Andersen, M.A., Wegener, K.M., Larsen, S., Badolo, L., Smith, G.P., Jeggo, R., Jensen, P.H., Sotty, F., Christensen, K.V., Thougaard, A., 2018b. PFE-360-induced LRRK2 inhibition induces reversible, non-adverse renal changes in rats. Toxicology 395, 15-22.

https://doi.org/10.1016/j.tox.2018.01.003

Anderson, J., Walker, D., Goldstein, J., de Laat, R., Banducci, K., Caccavello, R., Barbour, R., Huang, J., Kling, K., Lee, M., Diep, L., Keim, P., Shen, X., Chataway, T., Schlossmacher, M., Seubert, P., Schenk, D., Sinha, S., Gai, W., Chilcote, T., 2006. Phosphorylation of Ser-129 is the dominant pathological modification of alpha-synuclein in familial and sporadic Lewy body disease. J Biol Chem 281, 29739-29752.

Baba, M., Nakajo, S., Tu, P.H., Tomita, T., Nakaya, K., Lee, V.M., Trojanowski, J.Q., Iwatsubo, T., 1998. Aggregation of alpha-synuclein in Lewy bodies of sporadic Parkinson's disease and dementia with Lewy bodies. Am. J. Pathol. 152, 879-84.

Bae, E.-J., Kim, D.-K., Kim, C., Mante, M., Adame, A., Rockenstein, E., Ulusoy, A., Klinkenberg, M., Jeong, G.R., Bae, J.R., Lee, C., Lee, H.-J., Lee, B.-D., Di Monte, D.A., Masliah, E., Lee, S.-J., 2018. LRRK2 kinase regulates $\alpha$-synuclein propagation via RAB35 phosphorylation. Nat. Commun. 9, 3465. https://doi.org/10.1038/s41467-018-05958-z

Baptista, M.A.S., Dave, K.D., Frasier, M.A., Sherer, T.B., Greeley, M., Beck, M.J., Varsho, J.S., Parker, G.A., Moore, C., Churchill, M.J., Meshul, C.K., Fiske, B.K., 2013. Loss of Leucine-Rich Repeat Kinase 2 (LRRK2) in Rats Leads to Progressive Abnormal Phenotypes in Peripheral Organs. PLoS One 8, e80705. https://doi.org/10.1371/journal.pone.0080705

Bartels, T., Choi, J., Selkoe, D., 2011. a-Synuclein occurs physiologically as a helically folded tetramer that resists aggregation. Nature 477, 107.

Bendikov-Bar, I., Horowitz, M., 2012. Gaucher disease paradigm: from ERAD to comorbidity. Hum. Mutat. 33, 1398-407. https://doi.org/10.1002/humu.22124

Blauwendraat, C., Nalls, M.A., Singleton, A.B., 2019. The genetic architecture of Parkinson's disease. Lancet Neurol. https://doi.org/10.1016/s1474-4422(19)30287-x

Bonello, F., Hassoun, S.M., Mouton-Liger, F., Shin, Y.S., Muscat, A., Tesson, C., Lesage, S., Beart, P.M., Brice, A., Krupp, J., Corvol, J.C., Corti, O., 2019. LRRK2 impairs PINK1/Parkin-dependent mitophagy via its kinase activity: pathologic insights into Parkinson's disease. Hum. Mol. Genet. 28, 1645-1660. https://doi.org/10.1093/hmg/ddz004 
Boutin, M., Sun, Y., Shacka, J.J., Auray-Blais, C., 2016. Tandem Mass Spectrometry Multiplex Analysis of Glucosylceramide and Galactosylceramide Isoforms in Brain Tissues at Different Stages of Parkinson Disease. Anal. Chem. 88, 1856-1863.

https://doi.org/10.1021/acs.analchem.5b04227

Brahmachari, S., Ge, P., Lee, S.H., Kim, D., Karuppagounder, S.S., Kumar, M., Mao, X., Shin, J.H., Lee, Y., Pletnikova, O., Troncoso, J.C., Dawson, V.L., Dawson, T.M., Ko, H.S., 2016. Activation of tyrosine kinase c-Abl contributes to $\alpha$-synuclein-induced neurodegeneration. J. Clin. Invest. 126, 2970-2988.

Brundin, P., Melki, R., 2017. Prying into the Prion Hypothesis for Parkinson's Disease. J. Neurosci. 37, 9808-9818.

Brys, M., Fanning, L., Hung, S., Ellenbogen, A., Penner, N., Yang, M., Welch, M., Koenig, E., David, E., Fox, T., Makh, S., Aldred, J., Goodman, I., Pepinsky, B., Liu, Y., Graham, D., Weihofen, A., Cedarbaum, J., 2019. Randomized phase I clinical trial of anti- $\alpha$-synuclein antibody BIIB054. Mov Disord.

Burré, J., Sharma, M., Südhof, T., 2018. Cell Biology and Pathophysiology of $\alpha$-Synuclein. Cold Spring Harb Perspect Med 8, a024091.

Burré, J., Vivona, S., Diao, J., Sharma, M., Brunger, A.T., Südhof, T.C., 2013. Properties of native brain $\alpha$-synuclein. Nature 498, E4-6.

Cabrera-Salazar, M.A., Deriso, M., Bercury, S.D., Li, L., Lydon, J.T., Weber, W., Pande, N., Cromwell, M.A., Copeland, D., Leonard, J., Cheng, S.H., Scheule, R.K., 2012. Systemic delivery of a glucosylceramide synthase inhibitor reduces CNS substrates and increases lifespan in a mouse model of type 2 Gaucher disease. PLoS One 7, e43310.

https://doi.org/10.1371/journal.pone.0043310

Chang, D., Nalls, M.A., Hallgrímsdóttir, I.B., Hunkapiller, J., Brug, M. van der, Cai, F., Kerchner, G.A., Ayalon, G., Bingol, B., Sheng, M., Hinds, D., Behrens, T.W., Singleton, A.B., Bhangale, T.R., Graham, R.R., 2017. A meta-analysis of genome-wide association studies identifies 17 new Parkinson's disease risk loci. Nat. Genet. 49, 1511-1516. https://doi.org/10.1038/ng.3955

Chartier-Harlin, M.-C., Kachergus, J., Roumier, C., Mouroux, V., Douay, X., Lincoln, S., Levecque, C., Larvor, L., Andrieux, J., Hulihan, M., Waucquier, N., Defebvre, L., Amouyel, P., Farrer, M., Destée, A.,. Alpha-synuclein locus duplication as a cause of familial Parkinson's disease. Lancet 364, 1167-9. https://doi.org/10.1016/S0140-6736(04)17103-1

Chatterjee, D., Bhatt, M., Butler, D., De Genst, E., Dobson, C.M., Messer, A., Kordower, J.H., 2018. Proteasome-targeted nanobodies alleviate pathology and functional decline in an $\alpha$ synuclein-based Parkinson's disease model. NPJ Park. Dis. 4, 25.

Chen, L., Feany, M.B., 2005. $\alpha$-synuclein phosphorylation controls neurotoxicity and inclusion formation in a Drosophila model of Parkinson disease. Nat. Neurosci. 8, 657-63.

Choi, H.G., Zhang, J., Deng, X., Hatcher, J.M., Patricelli, M.P., Zhao, Z., Alessi, D.R., Gray, N.S., 2012. Brain Penetrant LRRK2 Inhibitor. ACS Med. Chem. Lett. 3, 658-662. https://doi.org/10.1021/ml300123a

Clark, L.N., Chan, R., Cheng, R., Liu, X., Park, N., Parmalee, N., Kisselev, S., Cortes, E., Torres, P.A., Pastores, G.M., Vonsattel, J.P., Alcalay, R., Marder, K., Honig, L.L., Fahn, S., Mayeux, R., Shelanski, M., Di Paolo, G., Lee, J.H., 2015. Gene-Wise Association of Variants in Four Lysosomal Storage Disorder Genes in Neuropathologically Confirmed Lewy Body Disease. PLoS One 10, e0125204. https://doi.org/10.1371/journal.pone.0125204

Cole, T., Paumier, K., Zhao, H., Weihofen, A., Kordasiewicz, H., Swayze, E., 2016. Snca targeted antisense oligonucleotides mediate progression of pathological deposition in alpha synuclein rodent transmission models of Parkinson's disease (P6.239). Neurology 86.

Collier, T.J., Eugene Redmond, D., Steece-Collier, K., Lipton, J.W., Manfredsson, F.P., 2016. Is 
alpha-synuclein loss-of-function a contributor to parkinsonian pathology? Evidence from nonhuman primates. Front. Neurosci. 10, 12.

Cooper, O., Seo, H., Andrabi, S., Guardia-Laguarta, C., Graziotto, J., Sundberg, M., McLean, J.R., Carrillo-Reid, L., Xie, Z., Osborn, T., Hargus, G., Deleidi, M., Lawson, T., Bogetofte, H., PerezTorres, E., Clark, L., Moskowitz, C., Mazzulli, J., Chen, L., Volpicelli-Daley, L., Romero, N., Jiang, H., Uitti, R.J., Huang, Z., Opala, G., Scarffe, L.A., Dawson, V.L., Klein, C., Feng, J., Ross, O.A., Trojanowski, J.Q., Lee, V.M.-Y., Marder, K., Surmeier, D.J., Wszolek, Z.K., Przedborski, S., Krainc, D., Dawson, T.M., Isacson, O., 2012. Pharmacological Rescue of Mitochondrial Deficits in iPSC-Derived Neural Cells from Patients with Familial Parkinson's Disease. Sci. Transl. Med.

4, 141ra90-141ra90. https://doi.org/10.1126/scitranslmed.3003985

Covy, J.P., Giasson, B.I., 2009. Identification of compounds that inhibit the kinase activity of leucine-rich repeat kinase 2. Biochem. Biophys. Res. Commun. 378, 473-477. https://doi.org/10.1016/j.bbrc.2008.11.048

Crews, L., Spencer, B., Desplats, P., Patrick, C., Paulino, A., Rockenstein, E., Hansen, L., Adame, A., Galasko, D., Masliah, E., 2010. Selective molecular alterations in the autophagy pathway in patients with lewy body disease and in models of $\alpha$-synucleinopathy. PLoS One 5, e9313.

Dahl, M., Doyle, A., Olsson, K., Månsson, J.E., Marques, A.R.A., Mirzaian, M., Aerts, J.M., Ehinger, M., Rothe, M., Modlich, U., Schambach, A., Karlsson, S., 2015. Lentiviral gene therapy using cellular promoters cures type 1 gaucher disease in mice. Mol. Ther. 23, 835-844. https://doi.org/10.1038/mt.2015.16

Dangouloff, T., Servais, L., 2019. Clinical Evidence Supporting Early Treatment Of Patients With Spinal Muscular Atrophy: Current Perspectives. Ther. Clin. Risk Manag. 15, 1153-1161. https://doi.org/10.2147/TCRM.S172291

Decressac, M., Mattsson, B., Weikop, P., Lundblad, M., Jakobsson, J., Bjorklund, A., 2013. TFEBmediated autophagy rescues midbrain dopamine neurons from $\alpha$-synuclein toxicity. Proc. Natl. Acad. Sci. 110, E1817-26.

Dehay, B., Bourdenx, M., Gorry, P., Przedborski, S., Vila, M., Hunot, S., Singleton, A., Olanow, C.W., Merchant, K.M., Bezard, E., Petsko, G.A., Meissner, W.G., 2015. Targeting $\alpha$-synuclein for treatment of Parkinson's disease: mechanistic and therapeutic considerations. Lancet Neurol $14,855-866$.

Dehay, B., Fernagut, P.-O., 2016. Alpha-synuclein-based models of Parkinson's disease. Rev. Neurol. (Paris). 172, 371-378.

Deng, X., Dzamko, N., Prescott, A., Davies, P., Liu, Q., Yang, Q., Lee, J.-D., Patricelli, M.P., Nomanbhoy, T.K., Alessi, D.R., Gray, N.S., 2011. Characterization of a selective inhibitor of the Parkinson's disease kinase LRRK2. Nat. Chem. Biol. 7, 203-205. https://doi.org/10.1038/nchembio.538

Desplats, P., Lee, H.-J., Bae, E.-J., Patrick, C., Rockenstein, E., Crews, L., Spencer, B., Masliah, E., Lee, S.-J., 2009. Inclusion formation and neuronal cell death through neuron-to-neuron transmission of -synuclein. Proc. Natl. Acad. Sci. 106, 13010-13015.

Di Maio, R., Hoffman, E.K., Rocha, E.M., Keeney, M.T., Sanders, L.H., De Miranda, B.R., Zharikov, A., Van Laar, A., Stepan, A.F., Lanz, T.A., Kofler, J.K., Burton, E.A., Alessi, D.R., Hastings, T.G., Timothy Greenamyre, J., 2018. LRRK2 activation in idiopathic Parkinson's disease. Sci. Transl. Med. 10, eaar5429. https://doi.org/10.1126/scitranslmed.aar5429

Diepenbroek, M., Casadei, N., Esmer, H., Saido, T.C., Takano, J., Kahle, P.J., Nixon, R.A., Rao, M. V, Melki, R., Pieri, L., 2014. Overexpression of the calpain-specific inhibitor calpastatin reduces human alpha- Synuclein processing, aggregation and synaptic impairment in [A30P] 2 Syn transgenic mice. Hum. Mol. Genet. 23, 3975-3989.

Divakaruni, A.S., Wallace, M., Buren, C., Martyniuk, K., Andreyev, A.Y., Li, E., Fields, J.A., Cordes, T., 
Reynolds, I.J., Bloodgood, B.L., Raymond, L.A., Metallo, C.M., Murphy, A.N., 2017. Inhibition of the mitochondrial pyruvate carrier protects from excitotoxic neuronal death. J. Cell Biol. 216, 1091-1105.

Dufty, B.M., Warner, L.R., Hou, S.T., Jiang, S.X., Gomez-Isla, T., Leenhouts, K.M., Oxford, J.T., Feany, M.B., Masliah, E., Rohn, T.T., 2007. Calpain-cleavage of $\alpha$-synuclein: Connecting proteolytic processing to disease-linked aggregation. Am. J. Pathol. 170, 1725-38.

Dzamko, N., Deak, M., Hentati, F., Reith, A.D., Prescott, A.R., Alessi, D.R., Nichols, R.J., 2010. Inhibition of LRRK2 kinase activity leads to dephosphorylation of Ser 910 /Ser 935 , disruption of 14-3-3 binding and altered cytoplasmic localization. Biochem. J. 430, 405-413. https://doi.org/10.1042/BJ20100784

Eldridge, R., Ince, S.E., 1984. The low concordance rate for Parkinson's disease in twins: a possible explanation. Neurology 34, 1354-6. https://doi.org/10.1212/wnl.34.10.1354

Enquist, I.B., Nilsson, E., Ooka, A., Månsson, J.-E., Olsson, K., Ehinger, M., Brady, R.O., Richter, J., Karlsson, S., 2006. Effective cell and gene therapy in a murine model of Gaucher disease. Proc. Natl. Acad. Sci. U. S. A. 103, 13819-24. https://doi.org/10.1073/pnas.0606016103

Estrada, A.A., Chan, B.K., Baker-Glenn, C., Beresford, A., Burdick, D.J., Chambers, M., Chen, H., Dominguez, S.L., Dotson, J., Drummond, J., Flagella, M., Fuji, R., Gill, A., Halladay, J., Harris, S.F., Heffron, T.P., Kleinheinz, T., Lee, D.W., Pichon, C.E.L., Liu, X., Lyssikatos, J.P., Medhurst, A.D., Moffat, J.G., Nash, K., Scearce-Levie, K., Sheng, Z., Shore, D.G., Wong, S., Zhang, S., Zhang, X., Zhu, H., Sweeney, Z.K., 2014. Discovery of highly potent, selective, and brainpenetrant aminopyrazole Leucine-rich repeat kinase 2 (LRRK2) small molecule inhibitors. J. Med. Chem. 57, 921-936. https://doi.org/10.1021/jm401654j

Estrada, A.A., Liu, X., Baker-Glenn, C., Beresford, A., Burdick, D.J., Chambers, M., Chan, B.K., Chen, H., Ding, X., DiPasquale, A.G., Dominguez, S.L., Dotson, J., Drummond, J., Flagella, M., Flynn, S., Fuji, R., Gill, A., Gunzner-Toste, J., Harris, S.F., Heffron, T.P., Kleinheinz, T., Lee, D.W., Le Pichon, C.E., Lyssikatos, J.P., Medhurst, A.D., Moffat, J.G., Mukund, S., Nash, K., Scearce-Levie, K., Sheng, Z., Shore, D.G., Tran, T., Trivedi, N., Wang, S., Zhang, S., Zhang, X., Zhao, G., Zhu, H., Sweeney, Z.K., 2012. Discovery of Highly Potent, Selective, and Brain-Penetrable Leucine-Rich Repeat Kinase 2 (LRRK2) Small Molecule Inhibitors. J. Med. Chem. 55, 9416-9433. https://doi.org/10.1021/jm301020q

Fan, Y., Howden, A.J.M., Sarhan, A.R., Lis, P., Ito, G., Martinez, T.N., Brockmann, K., Gasser, T., Alessi, D.R., Sammler, E.M., 2018. Interrogating Parkinson's disease LRRK2 kinase pathway activity by assessing Rab10 phosphorylation in human neutrophils. Biochem. J. 475, 23-44. https://doi.org/10.1042/BCJ20170803

Fell, M.J., Mirescu, C., Basu, K., Cheewatrakoolpong, B., DeMong, D.E., Ellis, J.M., Hyde, L.A., Lin, Y., Markgraf, C.G., Mei, H., Miller, M., Poulet, F.M., Scott, J.D., Smith, M.D., Yin, Z., Zhou, X., Parker, E.M., Kennedy, M.E., Morrow, J.A., 2015. MLi-2, a Potent, Selective, and Centrally Active Compound for Exploring the Therapeutic Potential and Safety of LRRK2 Kinase Inhibition. J. Pharmacol. Exp. Ther. 355, 397-409. https://doi.org/10.1124/jpet.115.227587

Fernandes, H.J.R., Hartfield, E.M., Christian, H.C., Emmanoulidou, E., Zheng, Y., Booth, H., Bogetofte, H., Lang, C., Ryan, B.J., Sardi, S.P., Badger, J., Vowles, J., Evetts, S., Tofaris, G.K., Vekrellis, K., Talbot, K., Hu, M.T., James, W., Cowley, S.A., Wade-Martins, R., 2016. ER Stress and Autophagic Perturbations Lead to Elevated Extracellular $\alpha$-Synuclein in GBA-N370S Parkinson's iPSC-Derived Dopamine Neurons. Stem cell reports 6, 342-56. https://doi.org/10.1016/j.stemcr.2016.01.013

Forlenza, O., De-Paula, V., Diniz, B., 2014. Neuroprotective effects of lithium: implications for the treatment of Alzheimer's disease and related neurodegenerative disorders. ACS Chem Neurosci 5, 443-50. 
Fuchs, J., Nilsson, C., Kachergus, J., Munz, M., Larsson, E.M., Schüle, B., Langston, J.W., Middleton, F.A., Ross, O.A., Hulihan, M., Gasser, T., Farrer, M.J., 2007. Phenotypic variation in a large Swedish pedigree due to SNCA duplication and triplication. Neurology 68, 916-22.

Fujiwara, H., Hasegawa, M., Dohmae, N., Kawashima, A., Masliah, E., Goldberg, M.S., Shen, J., Takio, K., Iwatsubo, T., 2002. $\alpha$-synuclein is phosphorylated in synucleinopathy lesions. Nat. Cell Biol. 4, 160-164.

Gan-Or, Z., Amshalom, I., Kilarski, L.L., Bar-Shira, A., Gana-Weisz, M., Mirelman, A., Marder, K., Bressman, S., Giladi, N., Orr-Urtreger, A., 2015. Differential effects of severe vs mild GBA mutations on Parkinson disease. Neurology 84, 880-887.

https://doi.org/10.1212/WNL.0000000000001315

Gegg, M.E., Burke, D., Heales, S.J.R.R., Cooper, J.M., Hardy, J., Wood, N.W., Schapira, A.H.V. V, 2012. Glucocerebrosidase deficiency in substantia nigra of parkinson disease brains. Ann. Neurol. 72, 455-463. https://doi.org/10.1002/ana.23614

Gegg, M.E., Schapira, A.H.V. V, 2018. The role of glucocerebrosidase in Parkinson disease pathogenesis. FEBS J. 285, 3591-3603. https://doi.org/10.1111/febs.14393

Gegg, Matthew E., Sweet, L., Wang, B.H., Shihabuddin, L.S., Sardi, S.P., Schapira, A.H.V., 2015. No evidence for substrate accumulation in Parkinson brains with GBA mutations. Mov. Disord. 30, 1085-1089. https://doi.org/10.1002/mds.26278

Gegg, Matthew E, Sweet, L., Wang, B.H., Shihabuddin, L.S., Sardi, S.P., Schapira, A.H. V, 2015. No evidence for substrate accumulation in Parkinson brains with GBA mutations. Mov. Disord. 30, 1085-9. https://doi.org/10.1002/mds.26278

Ghosh, A., Tyson, T., George, S., Hildebrandt, E.N., Steiner, J.A., Madaj, Z., Schulz, E., MacHiela, E., McDonald, W.G., Galvis, M.L.E., Kordower, J.H., Van Raamsdonk, J.M., Colca, J.R., Brundin, P., 2016. Mitochondrial pyruvate carrier regulates autophagy, inflammation, and neurodegeneration in experimental models of Parkinson's disease. Sci. Transl. Med. 8, 368 ra174.

Giasson, B.I., Duda, J.E., Murray, I.V.J., Chen, Q., Souza, J.M., Hurtig, H.I., Ischiropoulos, H., Trojanowski, J.Q., Lee, V.M.Y., 2000. Oxidative damage linked to neurodegeneration by selective $\alpha$-synuclein nitration in synucleinopathy lesions. Science (80-. ). 290, 985-989.

Gorbatyuk, O.S., Li, S., Nash, K., Gorbatyuk, M., Lewin, A.S., Sullivan, L.F., Mandel, R.J., Chen, W., Meyers, C., Manfredsson, F.P., Muzyczka, N., 2010. In vivo RNAi-mediated $\alpha$-synuclein silencing induces nigrostriatal degeneration. Mol. Ther. 18, 1450-7.

Gronich, N., Abernethy, D.R., Auriel, E., Lavi, I., Rennert, G., Saliba, W., 2018. $\beta 2$-adrenoceptor agonists and antagonists and risk of Parkinson's disease. Mov. Disord. 33, 1465-1471.

Hassen, G., Kesner, L., Stracher, A., Shulman, A., Rockenstein, E., Mante, M., Adame, A., Overk, C., Rissman, R., Masliah, E., 2018. Effects of Novel Calpain Inhibitors in Transgenic Animal Model of Parkinson's disease/dementia with Lewy bodies. Sci Rep 8, 18083.

Hatcher, J.M., Zhang, J., Choi, H.G., Ito, G., Alessi, D.R., Gray, N.S., 2015. Discovery of a pyrrolopyrimidine (JH-II-127), a highly potent, selective, and brain penetrant LRRK2 inhibitor. ACS Med. Chem. Lett. 6, 584-589. https://doi.org/10.1021/acsmedchemlett.5b00064

Healy, D.G., Falchi, M., O’Sullivan, S.S., Bonifati, V., Durr, A., Bressman, S., Brice, A., Aasly, J., Zabetian, C.P., Goldwurm, S., Ferreira, J.J., Tolosa, E., Kay, D.M., Klein, C., Williams, D.R., Marras, C., Lang, A.E., Wszolek, Z.K., Berciano, J., Schapira, A.H., Lynch, T., Bhatia, K.P., Gasser, T., Lees, A.J., Wood, N.W., 2008. Phenotype, genotype, and worldwide genetic penetrance of LRRK2-associated Parkinson's disease: a case-control study. Lancet Neurol. 7, 583-590. https://doi.org/10.1016/S1474-4422(08)70117-0

Hebron, M.L., Lonskaya, I., Moussa, C.E.H., 2013. Nilotinib reverses loss of dopamine neurons and improvesmotorbehavior via autophagic degradation of $\alpha$-synuclein in parkinson's disease 
models. Hum. Mol. Genet. 22, 3315-28.

Heinzel, S., Berg, D., Gasser, T., Chen, H., Yao, C., Postuma, R.B., 2019. Update of the MDS research criteria for prodromal Parkinson's disease. Mov. Disord. mds.27802.

https://doi.org/10.1002/mds.27802

Henderson, J.L., Kormos, B.L., Hayward, M.M., Coffman, K.J., Jasti, J., Kurumbail, R.G., Wager, T.T., Verhoest, P.R., Noell, G.S., Chen, Y., Needle, E., Berger, Z., Steyn, S.J., Houle, C., Hirst, W.D., Galatsis, P., 2015. Discovery and Preclinical Profiling of 3-[4-(Morpholin-4-yl)-7 H -pyrrolo[2,3d ]pyrimidin-5-yl]benzonitrile (PF-06447475), a Highly Potent, Selective, Brain Penetrant, and in Vivo Active LRRK2 Kinase Inhibitor. J. Med. Chem. 58, 419-432.

https://doi.org/10.1021/jm5014055

Hernandez, D.G., Reed, X., Singleton, A.B., 2016. Genetics in Parkinson disease: Mendelian versus non-Mendelian inheritance. J. Neurochem. https://doi.org/10.1111/jnc.13593

Herzig, M.C., Kolly, C., Persohn, E., Theil, D., Schweizer, T., Hafner, T., Stemmelen, C., Troxler, T.J., Schmid, P., Danner, S., Schnell, C.R., Mueller, M., Kinzel, B., Grevot, A., Bolognani, F., Stirn, M., Kuhn, R.R., Kaupmann, K., van der Putten, P.H., Rovelli, G., Shimshek, D.R., 2011. LRRK2 protein levels are determined by kinase function and are crucial for kidney and lung homeostasis in mice. Hum. Mol. Genet. 20, 4209-4223. https://doi.org/10.1093/hmg/ddr348

Hishida, R., Kurahashi, K., Narita, S., Baba, T., Matsunaga, M., 1992. "Wearing-off" and beta 2adrenoceptor agonist in Parkinson's disease. Lancet 339, 870.

Howlett, E.H., Jensen, N., Belmonte, F., Zafar, F., Hu, X., Kluss, J., Schüle, B., Kaufman, B.A., Greenamyre, J.T., Sanders, L.H., 2017. LRRK2 G2019S-induced mitochondrial DNA damage is LRRK2 kinase dependent and inhibition restores mtDNA integrity in Parkinson's disease. Hum. Mol. Genet. 26, 4340-4351. https://doi.org/10.1093/hmg/ddx320

Hruska, K.S., LaMarca, M.E., Scott, C.R., Sidransky, E., 2008. Gaucher disease: mutation and polymorphism spectrum in the glucocerebrosidase gene (GBA). Hum. Mutat. 29, 567-583. https://doi.org/10.1002/humu.20676

Hulihan, M.M., Ishihara-Paul, L., Kachergus, J., Warren, L., Amouri, R., Elango, R., Prinjha, R.K., Upmanyu, R., Kefi, M., Zouari, M., Sassi, S. Ben, Yahmed, S. Ben, El Euch-Fayeche, G., Matthews, P.M., Middleton, L.T., Gibson, R.A., Hentati, F., Farrer, M.J., 2008. LRRK2 Gly2019Ser penetrance in Arab-Berber patients from Tunisia: a case-control genetic study. Lancet Neurol. 7, 591-594. https://doi.org/10.1016/S1474-4422(08)70116-9

Janezic, S., Threlfell, S., Dodson, P.D., Dowie, M.J., Taylor, T.N., Potgieter, D., Parkkinen, L., Senior, S.L., Anwar, S., Ryan, B., Deltheil, T., Kosillo, P., Cioroch, M., Wagner, K., Ansorge, O., Bannerman, D.M., Bolam, J.P., Magill, P.J., Cragg, S.J., Wade-Martins, R., 2013. Deficits in dopaminergic transmission precede neuron loss and dysfunction in a new Parkinson model. Proc. Natl. Acad. Sci. U. S. A. 110, E4016.

Jankovic, J., Goodman, I., Safirstein, B., Marmon, T., Schenk, D., Koller, M., Zago, W., Ness, D., Griffith, S., 2018. Safety and Tolerability of Multiple Ascending Doses of PRX002/RG7935, an Anti- $\alpha$-Synuclein Monoclonal Antibody, in Patients With Parkinson Disease: A Randomized Clinical Trial. JAMA Neurol. 75, 1206-1214.

Johansen, K.K., Torp, S.H., Farrer, M.J., Gustavsson, E.K., Aasly, J.O., 2018. A Case of Parkinson's Disease with No Lewy Body Pathology due to a Homozygous Exon Deletion in Parkin. Case Rep. Neurol. Med. 2018, 1-4. https://doi.org/10.1155/2018/6838965

Kanaan, N., Manfredsson, F., 2012. Loss of functional alpha-synuclein: a toxic event in Parkinson's disease? J Park. Dis 2, 249-67.

Karuppagounder, S.S., Brahmachari, S., Lee, Y., Dawson, V.L., Dawson, T.M., Ko, H.S., 2014. The c$\mathrm{Abl}$ inhibitor, nilotinib, protects dopaminergic neurons in a preclinical animal model of Parkinson's disease. Sci. Rep. 4, 4874. 
Kellie, J.F., Higgs, R.E., Ryder, J.W., Major, A., Beach, T.G., Adler, C.H., Merchant, K., Knierman, M.D., 2014. Quantitative measurement of intact alpha-synuclein proteoforms from postmortem control and parkinson's disease brain tissue by intact protein mass spectrometry. Sci. Rep. 4, 5797.

Kim, S., Yun, S.P., Lee, S., Umanah, G.E., Bandaru, V.V.R., Yin, X., Rhee, P., Karuppagounder, S.S., Kwon, S.-H., Lee, H., Mao, X., Kim, D., Pandey, A., Lee, G., Dawson, V.L., Dawson, T.M., Ko, H.S., 2018. GBA1 deficiency negatively affects physiological $\alpha$-synuclein tetramers and related multimers. Proc. Natl. Acad. Sci. 115, 798-803. https://doi.org/10.1073/PNAS.1700465115

Krishnan, R., Hefti, F., Tsubery, H., Lulu, M., Proschitsky, M., Fisher, R., 2017. Conformation as the Therapeutic Target for Neurodegenerative Diseases. Curr Alzheimer Res 14, 393-402.

Krishnan, R., Tsubery, H., Proschitsky, M.Y., Asp, E., Lulu, M., Gilead, S., Gartner, M., Waltho, J.P., Davis, P.J., Hounslow, A.M., Kirschner, D.A., Inouye, H., Myszka, D.G., Wright, J., Solomon, B., Fisher, R.A., 2014. A bacteriophage capsid protein provides a general amyloid interaction motif (GAIM) that binds and remodels misfolded protein assemblies. J. Mol. Biol. 426, 250019.

Kumar, K., Djarmati-Westenberger, A., Grünewald, A., 2011. Genetics of Parkinson's Disease. Semin. Neurol. 31, 433-440. https://doi.org/10.1055/s-0031-1299782

Lavalley, N.J., Slone, S.R., Ding, H., West, A.B., Yacoubian, T.A., 2016. 14-3-3 Proteins regulate mutant LRRK2 kinase activity and neurite shortening. Hum. Mol. Genet. 25, 109-122. https://doi.org/10.1093/hmg/ddv453

Lee, A.J., Wang, Y., Alcalay, R.N., Mejia-Santana, H., Saunders-Pullman, R., Bressman, S., Corvol, J.C.C., Brice, A., Lesage, S., Mangone, G., Tolosa, E., Pont-Sunyer, C., Vilas, D., Schüle, B., Kausar, F., Foroud, T., Berg, D., Brockmann, K., Goldwurm, S., Siri, C., Asselta, R., RuizMartinez, J., Mondragón, E., Marras, C., Ghate, T., Giladi, N., Mirelman, A., Marder, K., 2017. Penetrance estimate of LRRK2 p.G2019S mutation in individuals of non-Ashkenazi Jewish ancestry. Mov. Disord. 32, 1432-1438. https://doi.org/10.1002/mds.27059

Lee, B.D., Shin, J.-H., VanKampen, J., Petrucelli, L., West, A.B., Ko, H.S., Lee, Y.-I., Maguire-Zeiss, K.A., Bowers, W.J., Federoff, H.J., Dawson, V.L., Dawson, T.M., Dawson, T.M., 2010. Inhibitors of leucine-rich repeat kinase-2 protect against models of Parkinson's disease. Nat. Med. 16, 998-1000. https://doi.org/10.1038/nm.2199

Lee, K.-W., Chen, W., Junn, E., Im, J.-Y., Grosso, H., Sonsalla, P.K., Feng, X., Ray, N., Fernandez, J.R., Chao, Y., Masliah, E., Voronkov, M., Braithwaite, S.P., Stock, J.B., Mouradian, M.M., 2011. Enhanced Phosphatase Activity Attenuates -Synucleinopathy in a Mouse Model. J. Neurosci. $31,6963-71$.

Lee, S.-J., 2008. Origins and effects of extracellular $\alpha$ synuclein: implications in Parkinson's disease. J Mol Neurosci 34, 17-22.

Lesage, S., Anheim, M., Condroyer, C., Pollak, P., Durif, F., Dupuits, C., Viallet, F., Lohmann, E., Corvol, J.C., Honoré, A., Rivaud, S., Vidailhet, M., Dürr, A., Brice, A., 2011. Large-scale screening of the Gaucher's disease-related glucocerebrosidase gene in Europeans with Parkinson's disease. Hum. Mol. Genet. 20, 202-210. https://doi.org/10.1093/hmg/ddq454

Levenson, J.M., Schroeter, S., Carroll, J.C., Cullen, V., Asp, E., Proschitsky, M., Chung, C.H.Y., Gilead, S., Nadeem, M., Dodiya, H.B., Shoaga, S., Mufson, E.J., Tsubery, H., Krishnan, R., Wright, J., Solomon, B., Fisher, R., Gannon, K.S., 2016. NPT088 reduces both amyloid- $\beta$ and tau pathologies in transgenic mice. Alzheimer's Dement. Transl. Res. Clin. Interv. 2, 141-155.

Lewis, J., Melrose, H., Bumcrot, D., Hope, A., Zehr, C., Lincoln, S., Braithwaite, A., He, Z., Ogholikhan, S., Hinkle, K., Kent, C., Toudjarska, I., Charisse, K., Braich, R., Pandey, R.K., Heckman, M., Maraganore, D.M., Crook, J., Farrer, M.J., 2008. In vivo silencing of alphasynuclein using naked siRNA. Mol. Neurodegener. 3, 19. 
Lindholm, D., Pham, D.D., Cascone, A., Eriksson, O., Wennerberg, K., Saarma, M., 2016. c-Abl Inhibitors Enable Insights into the pathophysiology and neuroprotection in Parkinson's disease. Front Aging Neurosci 8, 254.

Lindström, V., Ihse, E., Fagerqvist, T., Bergström, J., Nordström, E., Möller, C., Lannfelt, L., Ingelsson, M., 2014. Immunotherapy targeting $\alpha$-synuclein, with relevance for future treatment of Parkinson's disease and other Lewy body disorders. Immunotherapy 6, 141-53.

Liu, G.-H., Qu, J., Suzuki, K., Nivet, E., Li, M., Montserrat, N., Yi, F., Xu, X., Ruiz, S., Zhang, W., Wagner, U., Kim, A., Ren, B., Li, Y., Goebl, A., Kim, J., Soligalla, R.D., Dubova, I., Thompson, J., III, J.Y., Esteban, C.R., Sancho-Martinez, I., Belmonte, J.C.I., 2012. Progressive degeneration of human neural stem cells caused by pathogenic LRRK2. Nature 491, 603-607. https://doi.org/10.1038/nature11557

Liu, Z., Bryant, N., Kumaran, R., Beilina, A., Abeliovich, A., Cookson, M.R., West, A.B., 2018. LRRK2 phosphorylates membrane-bound Rabs and is activated by GTP-bound Rab7L1 to promote recruitment to the trans-Golgi network. Hum. Mol. Genet. 27, 385-395. https://doi.org/10.1093/hmg/ddx410

Lonskaya, I., Hebron, M.L., Desforges, N.M., Schachter, J.B., Moussa, C.E.H., 2014. Nilotinibinduced autophagic changes increase endogenous parkin level and ubiquitination, leading to amyloid clearance. J. Mol. Med. 92, 373-86.

Lorenzo-Betancor, O., Samaranch, L., Ezquerra, M., Tolosa, E., Lorenzo, E., Irigoyen, J., Gaig, C., Pastor, M.A., Soto-Ortolaza, A.I., Ross, O.A., Rodríguez-Oroz, M.C., Valldeoriola, F., Martí, M.J., Luquin, M.R., Perez-Tur, J., Burguera, J.A., Obeso, J.A., Pastor, P., 2012. LRRK2 haplotype-sharing analysis in Parkinson's disease reveals a novel p.S1761R mutation. Mov. Disord. 27, 146-150. https://doi.org/10.1002/mds.23968

Luk, K., Kehm, V., Carroll, J., Zhang, B., O’Brien, P., Trojanowski, J., Lee, V., 2012. Pathological $\alpha-$ synuclein transmission initiates Parkinson-like neurodegeneration in nontransgenic mice. Science (80-. ). 338, 949-53.

Maegawa, G.H.B., Tropak, M.B., Buttner, J.D., Rigat, B.A., Fuller, M., Pandit, D., Tang, L., Kornhaber, G.J., Hamuro, Y., Clarke, J.T.R., Mahuran, D.J., 2009. Identification and characterization of ambroxol as an enzyme enhancement agent for Gaucher disease. J. Biol. Chem. 284, 23502-16. https://doi.org/10.1074/jbc.M109.012393

Magistrelli, L., Comi, C., 2019. Beta2-Adrenoceptor Agonists in Parkinson's Disease and Other Synucleinopathies. J. Neuroimmune Pharmacol. s11481-018-09831-0. https://doi.org/10.1007/s11481-018-09831-0

Malini, E., Grossi, S., Deganuto, M., Rosano, C., Parini, R., Dominisini, S., Cariati, R., Zampieri, S., Bembi, B., Filocamo, M., Dardis, A., 2014. Functional analysis of 11 novel GBA alleles. Eur. J. Hum. Genet. 22, 511-516. https://doi.org/10.1038/ejhg.2013.182

Mamais, A., Raja, M., Manzoni, C., Dihanich, S., Lees, A., Moore, D., Lewis, P.A., Bandopadhyay, R., 2013. Divergent $\alpha$-synuclein solubility and aggregation properties in G2019S LRRK2 Parkinson's disease brains with Lewy Body pathology compared to idiopathic cases. Neurobiol. Dis. 58, 183-90.

Manning-Boğ, A.B., Schüle, B., Langston, J.W., 2009. Alpha-synuclein-glucocerebrosidase interactions in pharmacological Gaucher models: a biological link between Gaucher disease and parkinsonism. Neurotoxicology 30, 1127-32. https://doi.org/10.1016/j.neuro.2009.06.009

Marder, K., Wang, Y., Alcalay, R.N., Mejia-Santana, H., Tang, M.-X., Lee, A., Raymond, D., Mirelman, A., Saunders-Pullman, R., Clark, L., Ozelius, L., Orr-Urtreger, A., Giladi, N., Bressman, S., LRRK2 Ashkenazi Jewish Consortium, 2015. Age-specific penetrance of LRRK2 G2019S in the Michael J. Fox Ashkenazi Jewish LRRK2 Consortium. Neurology 85, 89-95. 
https://doi.org/10.1212/WNL.0000000000001708

Mazzulli, J.R., Xu, Y.H., Sun, Y., Knight, A.L., McLean, P.J., Caldwell, G.A., Sidransky, E., Grabowski, G.A., Krainc, D., 2011. Gaucher disease glucocerebrosidase and $\alpha$-synuclein form a bidirectional pathogenic loop in synucleinopathies. Cell 146, 37-52. https://doi.org/10.1016/j.cell.2011.06.001

Mazzulli, J.R., Zunke, F., Tsunemi, T., Toker, N.J., Jeon, S., Burbulla, L.F., Patnaik, S., Sidransky, E., Marugan, J.J., Sue, C.M., Krainc, D., 2016. Activation of $\beta$-glucocerebrosidase reduces pathological $\alpha$-synuclein and restores lysosomal function in Parkinson's patient midbrain neurons. J. Neurosci. 36, 7693-7706. https://doi.org/10.1523/JNEUROSCI.0628-16.2016

McCormack, A.L., Mak, S.K., Henderson, J.M., Bumcrot, D., Farrer, M.J., Di Monte, D.A., 2010. $\alpha-$ synuclein suppression by targeted small interfering RNA in the primate substantia nigra. PLoS One 5, e12122.

McFarthing, K., Simuni, T., 2019. Clinical Trial Highlights: Targeting Alpha-Synuclein. J. Parkinsons. Dis. 9, 5-16.

Melki, R., 2015. Role of Different Alpha-synuclein Strains in synucleinopathies, Similarities with other Neurodegenerative Diseases. J. Parkinsons. Dis. 5, 217-27.

Mena-Barragán, T., García-Moreno, M.I., Nanba, E., Higaki, K., Concia, A.L., Clapés, P., García Fernández, J.M., Ortiz Mellet, C., 2016. Inhibitor versus chaperone behaviour of $d$-fagomine, DAB and LAB sp2-iminosugar conjugates against glycosidases: A structure-activity relationship study in Gaucher fibroblasts. Eur. J. Med. Chem. 121, 880-891. https://doi.org/10.1016/j.ejmech.2015.08.038

Mercuri, E., Darras, B.T., Chiriboga, C.A., Day, J.W., Campbell, C., Connolly, A.M., lannaccone, S.T., Kirschner, J., Kuntz, N.L., Saito, K., Shieh, P.B., Tulinius, M., Mazzone, E.S., Montes, J., Bishop, K.M., Yang, Q., Foster, R., Gheuens, S., Bennett, C.F., Farwell, W., Schneider, E., De Vivo, D.C., Finkel, R.S., 2018. Nusinersen versus Sham Control in Later-Onset Spinal Muscular Atrophy. N. Engl. J. Med. 378, 625-635.

Migdalska-Richards, A., Schapira, A.H. V., 2016. The relationship between glucocerebrosidase mutations and Parkinson disease. J. Neurochem. 139, 77-90. https://doi.org/10.1111/jnc.13385

Mir, R., Tonelli, F., Lis, P., Macartney, T., Polinski, N.K., Martinez, T.N., Chou, M.Y., Howden, A.J.M., König, T., Hotzy, C., Milenkovic, I., Brücke, T., Zimprich, A., Sammler, E., Alessi, D.R., 2018. The Parkinson's disease VPS35[D620N] mutation enhances LRRK2-mediated Rab protein phosphorylation in mouse and human. Biochem. J. 475, 1861-1883. https://doi.org/10.1042/BCJ20180248

Mittal, S., Bjørnevik, K., Im, D.S., Flierl, A., Dong, X., Locascio, J.J., Abo, K.M., Long, E., Jin, M., Xu, B., Xiang, Y.K., Rochet, J.C., Engeland, A., Rizzu, P., Heutink, P., Bartels, T., Selkoe, D.J., Caldarone, B.J., Glicksman, M.A., Khurana, V., Schüle, B., Park, D.S., Riise, T., Scherzer, C.R., 2017. $\beta 2$-Adrenoreceptor is a regulator of the $\alpha$-synuclein gene driving risk of Parkinson's disease. Science (80-. ). 357, 891-898.

Ness, D., Ren, Z., Gardai, S., Sharpnack, D., Johnson, V.J., Brennan, R.J., Brigham, E.F., Olaharski, A.J., 2013. Leucine-Rich Repeat Kinase 2 (LRRK2)-Deficient Rats Exhibit Renal Tubule Injury and Perturbations in Metabolic and Immunological Homeostasis. PLoS One 8, e66164. https://doi.org/10.1371/journal.pone.0066164

Neumann, J., Bras, J., Deas, E., O’sullivan, S.S., Parkkinen, L., Lachmann, R.H., Li, A., Holton, J., Guerreiro, R., Paudel, R., Segarane, B., Singleton, A., Lees, A., Hardy, J., Houlden, H., Revesz, T., Wood, N.W., 2009. Glucocerebrosidase mutations in clinical and pathologically proven Parkinson's disease. Brain 132, 1783-1794. https://doi.org/10.1093/brain/awp044

Nichols, R.J., Dzamko, N., Hutti, J.E., Cantley, L.C., Deak, M., Moran, J., Bamborough, P., Reith, A.D., 
Alessi, D.R., 2009. Substrate specificity and inhibitors of LRRK2, a protein kinase mutated in Parkinson's disease. Biochem. J. 424, 47-60. https://doi.org/10.1042/BJ20091035

Orr-Urtreger, A., Shifrin, C., Rozovski, U., Rosner, S., Bercovich, D., Gurevich, T., Yagev-More, H., Bar-Shira, A., Giladi, N., 2007. The LRRK2 G2019S mutation in Ashkenazi Jews with Parkinson disease: Is there a gender effect? Neurology 69, 1595-1602.

https://doi.org/10.1212/01.wnl.0000277637.33328.d8

Oueslati, A., 2016. Implication of Alpha-synuclein Phosphorylation at S129 in synucleinopathies: What Have We Learned in the Last Decade? J Park. Dis 6, 39-51.

Oueslati, A., Schneider, B.L., Aebischer, P., Lashuel, H.A., 2013. Polo-like kinase 2 regulates selective autophagic alpha-synuclein clearance and suppresses its toxicity in vivo. Proc. Natl. Acad. Sci. 110, E3945-54.

Ozelius, L.J., Senthil, G., Saunders-Pullman, R., Ohmann, E., Deligtisch, A., Tagliati, M., Hunt, A.L., Klein, C., Henick, B., Hailpern, S.M., Lipton, R.B., Soto-Valencia, J., Risch, N., Bressman, S.B., 2006. LRRK2 G2019S as a Cause of Parkinson's Disease in Ashkenazi Jews. N. Engl. J. Med. 354, 424-425. https://doi.org/10.1056/NEJMc055509

Pagan, F., Hebron, M., Valadez, E.H., Torres-Yaghi, Y., Huang, X., Mills, R.R., Wilmarth, B.M., Howard, H., Dunn, C., Carlson, A., Lawler, A., Rogers, S.L., Falconer, R.A., Ahn, J., Li, Z., Moussa, C., 2016. Nilotinib effects in Parkinson's disease and dementia with lewy bodies. J. Parkinsons. Dis. 6, 503-17.

Pagan, F.L., Hebron, M.L., Wilmarth, B., Torres-Yaghi, Y., Lawler, A., Mundel, E.E., Yusuf, N., Starr, N.J., Arellano, J., Howard, H.H., Peyton, M., Matar, S., Liu, X., Fowler, A.J., Schwartz, S.L., Ahn, J., Moussa, C., 2019. Pharmacokinetics and pharmacodynamics of a single dose Nilotinib in individuals with Parkinson's disease. Pharmacol. Res. Perspect. 7, e00470.

Paisán-Ruíz, C., Jain, S., Evans, E.W., Gilks, W.P., Simón, J., Van Der Brug, M., De Munain, A.L., Aparicio, S., Gil, A.M., Khan, N., Johnson, J., Martinez, J.R., Nicholl, D., Carrera, I.M., Peňa, A.S., De Silva, R., Lees, A., Martí-Massó, J.F., Pérez-Tur, J., Wood, N.W., Singleton, A.B., 2004. Cloning of the gene containing mutations that cause PARK8-linked Parkinson's disease. Neuron 44, 595-600. https://doi.org/10.1016/j.neuron.2004.10.023

Pastores, G.M., Hughes, D.A., 1993. Gaucher Disease, GeneReviews ${ }^{\circledR}$. University of Washington, Seattle.

Peng, C., Gathagan, R., Lee, V., 2018. Distinct $\alpha$-Synuclein strains and implications for heterogeneity among $\alpha$-Synucleinopathies. Neurobiol. Dis. 109, 209-218.

Pieri, L., Madiona, K., Bousset, L., Melki, R., 2012. Fibrillar $\alpha$-synuclein and huntingtin exon 1 assemblies are toxic to the cells. Biophys. J. 102, 2894-2905.

Polymeropoulos, M.H., Lavedan, C., Leroy, E., Ide, S.E., Dehejia, A., Dutra, A., Pike, B., Root, H., Rubenstein, J., Boyer, R., Stenroos, E.S., Chandrasekharappa, S., Athanassiadou, A., Papapetropoulos, T., Johnson, W.G., Lazzarini, A.M., Duvoisin, R.C., Di lorio, G., Golbe, L.I., Nussbaum, R.L., 1997. Mutation in the alpha-synuclein gene identified in families with Parkinson's disease. Science 276, 2045-7.

Price, D.L., Koike, M.A., Khan, A., Wrasidlo, W., Rockenstein, E., Masliah, E., Bonhaus, D., 2018. The small molecule alpha-synuclein misfolding inhibitor, NPT200-11, produces multiple benefits in an animal model of Parkinson's disease. Sci. Rep. 8, 16165.

Qin, Q., Zhi, L.-T., Li, X.-T., Yue, Z.-Y., Li, G.-Z., Zhang, H., 2017. Effects of LRRK2 Inhibitors on Nigrostriatal Dopaminergic Neurotransmission. CNS Neurosci. Ther. 23, 162-173. https://doi.org/10.1111/cns.12660

Ramsden, N., Perrin, J., Ren, Z., Lee, B.D., Zinn, N., Dawson, V.L., Tam, D., Bova, M., Lang, M., Drewes, G., Bantscheff, M., Bard, F., Dawson, T.M., Hopf, C., 2011. Chemoproteomics-Based Design of Potent LRRK2-Selective Lead Compounds That Attenuate Parkinson's Disease- 
Related Toxicity in Human Neurons. ACS Chem. Biol. 6, 1021-1028.

https://doi.org/10.1021/cb2002413

Ray Dorsey, E., Elbaz, A., Nichols, E., Abd-Allah, F., Abdelalim, A., Adsuar, J.C., Ansha, M.G., Brayne,

C., Choi, J.Y.J., Collado-Mateo, D., Dahodwala, N., Do, H.P., Edessa, D., Endres, M.,

Fereshtehnejad, S.M., Foreman, K.J., Gankpe, F.G., Gupta, R., Hankey, G.J., Hay, S.I., Hegazy,

M.I., Hibstu, D.T., Kasaeian, A., Khader, Y., Khalil, I., Khang, Y.H., Kim, Y.J., Kokubo, Y.,

Logroscino, G., Massano, J., Ibrahim, N.M., Mohammed, M.A., Mohammadi, A., Moradi-

Lakeh, M., Naghavi, M., Nguyen, B.T., Nirayo, Y.L., Ogbo, F.A., Owolabi, M.O., Pereira, D.M.,

Postma, M.J., Qorbani, M., Rahman, M.A., Roba, K.T., Safari, H., Safiri, S., Satpathy, M.,

Sawhney, M., Shafieesabet, A., Shiferaw, M.S., Smith, M., Szoeke, C.E.I., Tabarés-Seisdedos,

R., Truong, N.T., Ukwaja, K.N., Venketasubramanian, N., Villafaina, S., Weldegwergs, K.G.,

Westerman, R., Wijeratne, T., Winkler, A.S., Xuan, B.T., Yonemoto, N., Feigin, V.L., Vos, T., Murray, C.J.L., 2018. Global, regional, and national burden of Parkinson's disease, 1990-2016: a systematic analysis for the Global Burden of Disease Study 2016. Lancet Neurol. 17, 939953. https://doi.org/10.1016/S1474-4422(18)30295-3

Rocha, E.M., Smith, G.A., Park, E., Cao, H., Brown, E., Hallett, P., Isacson, O., 2015. Progressive decline of glucocerebrosidase in aging and Parkinson's disease. Ann. Clin. Transl. Neurol. 2, 433-8. https://doi.org/10.1002/acn3.177

Ross, O.A., Soto-Ortolaza, A.I., Heckman, M.G., Aasly, J.O., Abahuni, N., Annesi, G., Bacon, J.A., Bardien, S., Bozi, M., Brice, A., Brighina, L., Van Broeckhoven, C., Carr, J., Chartier-Harlin, M.C., Dardiotis, E., Dickson, D.W., Diehl, N.N., Elbaz, A., Ferrarese, C., Ferraris, A., Fiske, B., Gibson, J.M., Gibson, R., Hadjigeorgiou, G.M., Hattori, N., Ioannidis, J.P.A., Jasinska-Myga, B., Jeon, B.S., Kim, Y.J., Klein, C., Kruger, R., Kyratzi, E., Lesage, S., Lin, C.-H., Lynch, T., Maraganore, D.M., Mellick, G.D., Mutez, E., Nilsson, C., Opala, G., Park, S.S., Puschmann, A., Quattrone, A., Sharma, M., Silburn, P.A., Sohn, Y.H., Stefanis, L., Tadic, V., Theuns, J., Tomiyama, H., Uitti, R.J., Valente, E.M., van de Loo, S., Vassilatis, D.K., Vilariño-Güell, C., White, L.R., Wirdefeldt, K., Wszolek, Z.K., Wu, R.-M., Farrer, M.J., Genetic Epidemiology Of Parkinson's Disease (GEO-PD) Consortium, 2011. Association of LRRK2 exonic variants with susceptibility to Parkinson's disease: a case-control study. Lancet. Neurol. 10, 898-908. https://doi.org/10.1016/S1474-4422(11)70175-2

Rubio, J.P., Topp, S., Warren, L., St Jean, P.L., Wegmann, D., Kessner, D., Novembre, J., Shen, J., Fraser, D., Aponte, J., Nangle, K., Cardon, L.R., Ehm, M.G., Chissoe, S.L., Whittaker, J.C., Nelson, M.R., Mooser, V.E., 2012. Deep sequencing of the LRRK2 gene in 14,002 individuals reveals evidence of purifying selection and independent origin of the p.Arg1628Pro mutation in Europe. Hum. Mutat. 33, 1087-98. https://doi.org/10.1002/humu.22075

Saito, Y., Kawashima, A., Ruberu, N., Fujiwara, H., Koyama, S., Sawabe, M., Arai, T., Nagura, H., Yamanouchi, H., Hasegawa, M., Iwatsubo, T., Murayama, S., 2003. Accumulation of phosphorylated alpha-synuclein in aging human brain. J Neuropathol Exp Neurol 62, 644654.

Sapru, M.K., Yates, J.W., Hogan, S., Jiang, L., Halter, J., Bohn, M.C., 2006. Silencing of human $\alpha-$ synuclein in vitro and in rat brain using lentiviral-mediated RNAi. Exp. Neurol. 198, 382-90.

Sardi, S.P., Cedarbaum, J.M., Brundin, P., 2018. Targeted Therapies for Parkinson's Disease: From Genetics to the Clinic. Mov. Disord. https://doi.org/10.1002/mds.27414

Sardi, S.P., Viel, C., Clarke, J., Treleaven, C.M., Richards, A.M., Park, H., Olszewski, M.A., Dodge, J.C., Marshall, J., Makino, E., Wang, B., Sidman, R.L., Cheng, S.H., Shihabuddin, L.S., 2017. Glucosylceramide synthase inhibition alleviates aberrations in synucleinopathy models. Proc. Natl. Acad. Sci. U. S. A. 114, 2699-2704. https://doi.org/10.1073/pnas.1616152114

Satake, W., Nakabayashi, Y., Mizuta, I., Hirota, Y., Ito, C., Kubo, M., Kawaguchi, T., Tsunoda, T., 
Watanabe, M., Takeda, A., Tomiyama, H., Nakashima, K., Hasegawa, K., Obata, F., Yoshikawa, T., Kawakami, H., Sakoda, S., Yamamoto, M., Hattori, N., Murata, M., Nakamura, Y., Toda, T., 2009. Genome-wide association study identifies common variants at four loci as genetic risk factors for Parkinson's disease. Nat. Genet. 41, 1303-1307. https://doi.org/10.1038/ng.485

Sato, H., Arawaka, S., Hara, S., Fukushima, S., Koga, K., Koyama, S., Kato, T., 2011. Authentically Phosphorylated alpha-synuclein at Ser129 Accelerates Neurodegeneration in a Rat Model of Familial Parkinson's Disease. J. Neurosci. 31, 16884-94.

Sawkar, A.R., Cheng, W.-C., Beutler, E., Wong, C.-H., Balch, W.E., Kelly, J.W., 2002. Chemical chaperones increase the cellular activity of N370S beta -glucosidase: a therapeutic strategy for Gaucher disease. Proc. Natl. Acad. Sci. U. S. A. 99, 15428-33. https://doi.org/10.1073/pnas.192582899

Schöndorf, D.C., Aureli, M., McAllister, F.E., Hindley, C.J., Mayer, F., Schmid, B., Sardi, S.P., Valsecchi, M., Hoffmann, S., Schwarz, L.K., Hedrich, U., Berg, D., Shihabuddin, L.S., Hu, J., Pruszak, J., Gygi, S.P., Sonnino, S., Gasser, T., Deleidi, M., 2014a. IPSC-derived neurons from GBA1-associated Parkinson's disease patients show autophagic defects and impaired calcium homeostasis. Nat. Commun. 5, 4028. https://doi.org/10.1038/ncomms5028

Schöndorf, D.C., Aureli, M., McAllister, F.E., Hindley, C.J., Mayer, F., Schmid, B., Sardi, S.P., Valsecchi, M., Hoffmann, S., Schwarz, L.K., Hedrich, U., Berg, D., Shihabuddin, L.S., Hu, J., Pruszak, J., Gygi, S.P., Sonnino, S., Gasser, T., Deleidi, M., 2014b. iPSC-derived neurons from GBA1-associated Parkinson's disease patients show autophagic defects and impaired calcium homeostasis. Nat. Commun. 5, 4028. https://doi.org/10.1038/ncomms5028

Schwab, A.J., Ebert, A.D., 2015. Neurite Aggregation and Calcium Dysfunction in iPSC-Derived Sensory Neurons with Parkinson's Disease-Related LRRK2 G2019S Mutation. Stem Cell Reports 5, 1039-1052. https://doi.org/10.1016/j.stemcr.2015.11.004

Scott, J.D., DeMong, D.E., Greshock, T.J., Basu, K., Dai, X., Harris, J., Hruza, A., Li, S.W., Lin, S.-I., Liu, H., Macala, M.K., Hu, Z., Mei, H., Zhang, H., Walsh, P., Poirier, M., Shi, Z.-C., Xiao, L., Agnihotri, G., Baptista, M.A.S., Columbus, J., Fell, M.J., Hyde, L.A., Kuvelkar, R., Lin, Y., Mirescu, C., Morrow, J.A., Yin, Z., Zhang, X., Zhou, X., Chang, R.K., Embrey, M.W., Sanders, J.M., Tiscia, H.E., Drolet, R.E., Kern, J.T., Sur, S.M., Renger, J.J., Bilodeau, M.T., Kennedy, M.E., Parker, E.M., Stamford, A.W., Nargund, R., McCauley, J.A., Miller, M.W., 2017. Discovery of a 3-(4Pyrimidinyl) Indazole (MLi-2), an Orally Available and Selective Leucine-Rich Repeat Kinase 2 (LRRK2) Inhibitor that Reduces Brain Kinase Activity. J. Med. Chem. 60, 2983-2992. https://doi.org/10.1021/acs.jmedchem.7b00045

Sevigny, J., Chiao, P., Bussière, T., Weinreb, P.H., Williams, L., Maier, M., Dunstan, R., Salloway, S., Chen, T., Ling, Y., O'Gorman, J., Qian, F., Arastu, M., Li, M., Chollate, S., Brennan, M.S., Quintero-Monzon, O., Scannevin, R.H., Arnold, H.M., Engber, T., Rhodes, K., Ferrero, J., Hang, Y., Mikulskis, A., Grimm, J., Hock, C., Nitsch, R.M., Sandrock, A., 2016. The antibody aducanumab reduces $A \beta$ plaques in Alzheimer's disease. Nature 537, 50-6.

Shayman, J.A., Larsen, S.D., 2014. The development and use of small molecule inhibitors of glycosphingolipid metabolism for lysosomal storage diseases. J. Lipid Res. 55, 1215-1225. https://doi.org/10.1194/jlr.R047167

Sheng, Z., Zhang, S., Bustos, D., Kleinheinz, T., Le Pichon, C.E., Dominguez, S.L., Solanoy, H.O., Drummond, J., Zhang, X., Ding, X., Cai, F., Song, Q., Li, X., Yue, Z., van der Brug, M.P., Burdick, D.J., Gunzner-Toste, J., Chen, H., Liu, X., Estrada, A.A., Sweeney, Z.K., Scearce-Levie, K., Moffat, J.G., Kirkpatrick, D.S., Zhu, H., 2012. Ser1292 Autophosphorylation Is an Indicator of LRRK2 Kinase Activity and Contributes to the Cellular Effects of PD Mutations. Sci. Transl. Med. 4, 164ra161-164ra161. https://doi.org/10.1126/scitranslmed.3004485

Sidransky, E., Nalls, M.A.A., Aasly, J.O.O., Aharon-Peretz, J., Annesi, G., Barbosa, E.R.R., Bar-Shira, 
A., Berg, D., Bras, J., Brice, A., Chen, C.-M.C.-M., Clark, L.N.N., Condroyer, C., De Marco, E.V. V, Dürr, A., Eblan, M.J.J., Fahn, S., Farrer, M.J.J., Fung, H.-C.H.-C., Gan-Or, Z., Gasser, T., Gershoni-Baruch, R., Giladi, N., Griffith, A., Gurevich, T., Januario, C., Kropp, P., Lang, A.E.E., Lee-Chen, G.-J.G.-J., Lesage, S., Marder, K., Mata, I.F.F., Mirelman, A., Mitsui, J., Mizuta, I., Nicoletti, G., Oliveira, C., Ottman, R., Orr-Urtreger, A., Pereira, L.V. V, Quattrone, A., Rogaeva, E., Rolfs, A., Rosenbaum, H., Rozenberg, R., Samii, A., Samaddar, T., Schulte, C., Sharma, M., Singleton, A., Spitz, M., Tan, E.-K.E.-K., Tayebi, N., Toda, T., Troiano, A.R.R., Tsuji, S., Wittstock, M., Wolfsberg, T.G.G., Wu, Y.-R.Y.-R., Zabetian, C.P.P., Zhao, Y., Ziegler, S.G.G., 2009. Multicenter analysis of glucocerebrosidase mutations in Parkinson's disease. N. Engl. J. Med. 361, 1651-61. https://doi.org/10.1056/NEJMoa0901281

Siebert, M., Sidransky, E., Westbroek, W., 2014. Glucocerebrosidase is shaking up the synucleinopathies. Brain 137, 1304-1322. https://doi.org/10.1093/brain/awu002

Singleton, A.B., Farrer, M., Johnson, J., Singleton, A., Hague, S., Kachergus, J., Hulihan, M., Peuralinna, T., Dutra, A., Nussbaum, R., Lincoln, S., Crawley, A., Hanson, M., Maraganore, D., Adler, C., Cookson, M.R., Muenter, M., Baptista, M., Miller, D., Blancato, J., Hardy, J., GwinnHardy, K., 2003. alpha-Synuclein locus triplication causes Parkinson's disease. Science 302, 841. https://doi.org/10.1126/science.1090278

Smith, G.A., Jansson, J., Rocha, E.M., Osborn, T., Hallett, P.J., Isacson, O., 2016. Fibroblast Biomarkers of Sporadic Parkinson's Disease and LRRK2 Kinase Inhibition. Mol. Neurobiol. 53, 5161-5177. https://doi.org/10.1007/s12035-015-9435-4

Smith, L., Mullin, S., Schapira, A.H. V, 2017. Insights into the structural biology of Gaucher disease. Exp. Neurol. 298, 180-190. https://doi.org/10.1016/j.expneurol.2017.09.010

Spillantini, M.G., Schmidt, M.L., Lee, V.M.Y., Trojanowski, J.Q., Jakes, R., Goedert, M., 1997. $\alpha-$ synuclein in Lewy bodies. Nature 388, 839-40.

Steet, R.A., Chung, S., Wustman, B., Powe, A., Do, H., Kornfeld, S.A., 2006. The iminosugar isofagomine increases the activity of N370S mutant acid beta-glucosidase in Gaucher fibroblasts by several mechanisms. Proc. Natl. Acad. Sci. U. S. A. 103, 13813-8. https://doi.org/10.1073/pnas.0605928103

Steger, M., Tonelli, F., Ito, G., Davies, P., Trost, M., Vetter, M., Wachter, S., Lorentzen, E., Duddy, G., Wilson, S., Baptista, M.A., Fiske, B.K., Fell, M.J., Morrow, J.A., Reith, A.D., Alessi, D.R., Mann, M., 2016. Phosphoproteomics reveals that Parkinson's disease kinase LRRK2 regulates a subset of Rab GTPases. Elife 5. https://doi.org/10.7554/eLife.12813

Stirnemann, J.Ô., Belmatoug, N., Camou, F., Serratrice, C., Froissart, R., Caillaud, C., Levade, T., Astudillo, L., Serratrice, J., Brassier, A., Rose, C., De Villemeur, T.B., Berger, M.G., 2017. A review of gaucher disease pathophysiology, clinical presentation and treatments. Int. J. Mol. Sci. https://doi.org/10.3390/ijms18020441

Suzuki, M., Fujikake, N., Takeuchi, T., Kohyama-Koganeya, A., Nakajima, K., Hirabayashi, Y., Wada, K., Nagai, Y., 2015. Glucocerebrosidase deficiency accelerates the accumulation of proteinase K-resistant $\alpha$-synuclein and aggravates neurodegeneration in a Drosophila model of Parkinson's disease. Hum. Mol. Genet. 24, 6675-6686. https://doi.org/10.1093/hmg/ddv372

Takeda, A., Mallory, M., Sundsmo, M., Honer, W., Hansen, L., Masliah, E., 1998. Abnormal accumulation of NACP/alpha-synuclein in neurodegenerative disorders. Am J Pathol 152, 367-72.

Tanabe, A., Yamamura, Y., Kasahara, J., Morigaki, R., Kaji, R., Goto, S., 2014. A novel tyrosine kinase inhibitor AMN107 (nilotinib) normalizes striatal motor behaviors in a mouse model of Parkinson's disease. Front. Cell. Neurosci. 8, 50.

Theillet, F.X., Binolfi, A., Bekei, B., Martorana, A., Rose, H.M., Stuiver, M., Verzini, S., Lorenz, D., Van Rossum, M., Goldfarb, D., Selenko, P., 2016. Structural disorder of monomeric $\alpha$ - 
synuclein persists in mammalian cells. Nature 530, 45-50.

Thirstrup, K., Dächsel, J.C., Oppermann, F.S., Williamson, D.S., Smith, G.P., Fog, K., Christensen, K. V., 2017. Selective LRRK2 kinase inhibition reduces phosphorylation of endogenous Rab10 and Rab12 in human peripheral mononuclear blood cells. Sci. Rep. 7, 10300. https://doi.org/10.1038/s41598-017-10501-z

Thiruchelvam, M.J., Powers, J.M., Cory-Slechta, D.A., Richfield, E.K., 2004. Risk factors for dopaminergic neuron loss in human $\alpha$-synuclein transgenic mice. Eur. J. Neurosci. 19, 845854.

Tofaris, G.K., Razzaq, A., Ghetti, B., Lilley, K.S., Spillantini, M.G., 2003. Ubiquitination of $\alpha$-Synuclein in Lewy Bodies Is a Pathological Event Not Associated with Impairment of Proteasome Function. J. Biol. Chem. 278, 44405-44411.

Toffoli, M., Smith, L., Schapira, A.H. V., 2020. The biochemical basis of interactions between Glucocerebrosidase and alpha-synuclein in GBA 1 mutation carriers. J. Neurochem. jnc.14968. https://doi.org/10.1111/jnc.14968

Tong, Y., Giaime, E., Yamaguchi, H., Ichimura, T., Liu, Y., Si, H., Cai, H., Bonventre, J. V, Shen, J., 2012. Loss of leucine-rich repeat kinase 2 causes age-dependent bi-phasic alterations of the autophagy pathway. Mol. Neurodegener. 7, 2. https://doi.org/10.1186/1750-1326-7-2

Tsika, E., Moysidou, M., Guo, J., Cushman, M., Gannon, P., Sandaltzopoulos, R., Giasson, B.I., Krainc, D., Ischiropoulos, H., Mazzulli, J.R., 2010. Distinct Region-Specific $\alpha$-Synuclein Oligomers in A53T Transgenic Mice: Implications for Neurodegeneration. J. Neurosci. 30, 3409-18.

Uc, E.Y., Lambert, C.P., Harik, S.I., Rodnitzky, R.L., Evans, W.J., 2003. Albuterol improves response to levodopa and increases skeletal muscle mass in patients with fluctuating Parkinson disease. Clin. Neuropharmacol. 26, 207-12.

Vacanti, N.M., Divakaruni, A.S., Green, C.R., Parker, S.J., Henry, R.R., Ciaraldi, T.P., Murphy, A.N., Metallo, C.M., 2014. Regulation of substrate utilization by the mitochondrial pyruvate carrier. Mol. Cell 56, 425-35.

Vilariño-Güell, C., Wider, C., Ross, O.A., Dachsel, J.C., Kachergus, J.M., Lincoln, S.J., Soto-Ortolaza, A.I., Cobb, S.A., Wilhoite, G.J., Bacon, J.A., Bahareh Behrouz, Melrose, H.L., Hentati, E., Puschmann, A., Evans, D.M., Conibear, E., Wasserman, W.W., Aasly, J.O., Burkhard, P.R., Djaldetti, R., Ghika, J., Hentati, F., Krygowska-Wajs, A., Lynch, T., Melamed, E., Rajput, A., Rajput, A.H., Solida, A., Wu, R.M., Uitti, R.J., Wszolek, Z.K., Vingerhoets, F., Farrer, M.J., 2011. VPS35 mutations in parkinson disease. Am. J. Hum. Genet. 89, 162-167. https://doi.org/10.1016/j.ajhg.2011.06.001

Volpicelli-Daley, L.A., Luk, K.C., Patel, T.P., Tanik, S.A., Riddle, D.M., Stieber, A., Meaney, D.F., Trojanowski, J.Q., Lee, V.M.Y., 2011. Exogenous $\alpha$-Synuclein Fibrils Induce Lewy Body Pathology Leading to Synaptic Dysfunction and Neuron Death. Neuron 72, 57-71.

Wakamatsu, M., Ishii, A., Iwata, S., Sakagami, J., Ukai, Y., Ono, M., Kanbe, D., Muramatsu, S. ichi, Kobayashi, K., Iwatsubo, T., Yoshimoto, M., 2008. Selective loss of nigral dopamine neurons induced by overexpression of truncated human $\alpha$-synuclein in mice. Neurobiol. Aging 29, 574-585.

Ward, C.D., Duvoisin, R.C., Ince, S.E., Nutt, J.D., Eldridge, R., Calne, D.B., 1983. Parkinson's disease in 65 pairs of twins and in a set of quadruplets. Neurology 33, 815-24. https://doi.org/10.1212/wnl.33.7.815

Webb, J.L., Ravikumar, B., Atkins, J., Skepper, J.N., Rubinsztein, D.C., 2003. $\alpha$-synuclein Is Degraded by Both Autophagy and the Proteasome. J. Biol. Chem. 278, 25009-13.

Weinreb, P.H., Zhen, W., Poon, A.W., Conway, K.A., Lansbury, P.T., 1996. NACP, a protein implicated in Alzheimer's disease and learning, is natively unfolded. Biochemistry 35, 13709- 
13715.

West, A.B., Moore, D.J., Biskup, S., Bugayenko, A., Smith, W.W., Ross, C.A., Dawson, V.L., Dawson, T.M., 2005. Parkinson's disease-associated mutations in leucine-rich repeat kinase 2 augment kinase activity. Proc. Natl. Acad. Sci. U. S. A. 102, 16842-7. https://doi.org/10.1073/pnas.0507360102

Wild, E., Tabrizi, S., 2017. Therapies targeting DNA and RNA in Huntington's disease. Lancet Neurol $16,837-847$.

Wu, X., Tang, K.-F., Li, Y., Xiong, Y.-Y., Shen, L., Wei, Z.-Y., Zhou, K.-J., Niu, J.-M., Han, X., Yang, L., Feng, G.-Y., He, L., Qin, S.-Y., 2012. Quantitative assessment of the effect of LRRK2 exonic variants on the risk of Parkinson's disease: A meta-analysis. Parkinsonism Relat. Disord. 18, 722-730. https://doi.org/10.1016/J.PARKRELDIS.2012.04.013

Wyse, R., Brundin, P., Sherer, T., 2016. Nilotinib - Differentiating the Hope from the Hype. J Park. Dis 6, 519-522.

Xilouri, M., Brekk, O., Stefanis, L., 2016. Autophagy and alpha-synuclein: relevance to Parkinson's disease and related synucleopathies. Mov Disord 31, 178-92.

Xiong, Y., Neifert, S., Karuppagounder, S.S., Liu, Q., Stankowski, J.N., Lee, B.D., Ko, H.S., Lee, Y., Grima, J.C., Mao, X., Jiang, H., Kang, S.-U., Swing, D.A., lacovitti, L., Tessarollo, L., Dawson, T.M., Dawson, V.L., 2018. Robust kinase- and age-dependent dopaminergic and norepinephrine neurodegeneration in LRRK2 G2019S transgenic mice. Proc. Natl. Acad. Sci. U. S. A. 115, 1635-1640. https://doi.org/10.1073/pnas.1712648115

Yao, C., Johnson, W.M., Gao, Y., Wang, W., Zhang, J., Deak, M., Alessi, D.R., Zhu, X., Mieyal, J.J., Roder, H., Wilson-Delfosse, A.L., Chen, S.G., 2013. Kinase inhibitors arrest neurodegeneration in cell and C. elegans models of LRRK2 toxicity. Hum. Mol. Genet. 22, 328-344. https://doi.org/10.1093/hmg/dds431

Zella, M., Metzdorf, J., Ostendorf, F., Maass, F., Muhlack, S., Gold, R., Haghikia, A., Tönges, L., 2019. Novel Immunotherapeutic Approaches to Target Alpha-Synuclein and Related Neuroinflammation in Parkinson's Disease. Cells 8, 105.

Zhang, J., Deng, X., Choi, H.G., Alessi, D.R., Gray, N.S., 2012. Characterization of TAE684 as a potent LRRK2 kinase inhibitor. Bioorg. Med. Chem. Lett. 22, 1864-1869. https://doi.org/10.1016/j.bmcl.2012.01.084

Zhao, Y., Dzamko, N., 2019. Recent Developments in LRRK2-Targeted Therapy for Parkinson's Disease. Drugs 79, 1037-1051. https://doi.org/10.1007/s40265-019-01139-4

Zharikov, A.D., Cannon, J.R., Tapias, V., Bai, Q., Horowitz, M.P., Shah, V., El Ayadi, A., Hastings, T.G., Greenamyre, J.T., Burton, E.A., 2015. ShRNA targeting $\alpha$-synuclein prevents neurodegeneration in a Parkinson's disease model. J. Clin. Invest. 125, 2721-2735.

Zheng, W., Padia, J., Urban, D.J., Jadhav, A., Goker-Alpan, O., Simeonov, A., Goldin, E., Auld, D., LaMarca, M.E., Inglese, J., Austin, C.P., Sidransky, E., 2007. Three classes of glucocerebrosidase inhibitors identified by quantitative high-throughput screening are chaperone leads for Gaucher disease. Proc. Natl. Acad. Sci. U. S. A. 104, 13192-7. https://doi.org/10.1073/pnas.0705637104

Zimprich, A., Biskup, S., Leitner, P., Lichtner, P., Farrer, M., Lincoln, S., Kachergus, J., Hulihan, M., Uitti, R.J., Calne, D.B., Stoessl, A.J., Pfeiffer, R.F., Patenge, N., Carbajal, I.C., Vieregge, P., Asmus, F., Müller-Myhsok, B., Dickson, D.W., Meitinger, T., Strom, T.M., Wszolek, Z.K., Gasser, T., 2004. Mutations in LRRK2 cause autosomal-dominant parkinsonism with pleomorphic pathology. Neuron 44,601-607. https://doi.org/10.1016/j.neuron.2004.11.005 